\title{
Storms, channel changes, and a sediment budget for an urban- suburban stream, Difficult Run, Virginia, USA
}

\author{
Gellis, A.C. ${ }^{1}$, Myers, M.K. ${ }^{2}$, Noe, G.B. ${ }^{3}$, Hupp, C.R. ${ }^{3}$, Schenk, E.R. ${ }^{4}$, and Myers, L. ${ }^{1}$ \\ ${ }^{1}$ U.S. Geological Survey, Maryland Water Science Center, 5522 Research Park Dr., Baltimore, \\ MD 21228 \\ ${ }^{2}$ U.S. Geological Survey, Pennsylvania Water Science Center, 215 Limekiln Road, New \\ Cumberland PA 17070 \\ ${ }^{3}$ U.S. Geological Survey, Nation Research Program, 12201 Sunrise Valley Drive, Reston, VA 20192 \\ ${ }^{4}$ National Park Service, 129 Grand Canyon, AZ 86023
}

\begin{abstract}
Determining erosion and deposition rates in urban-suburban settings and how these processes are affected by large storms is important to understanding geomorphic processes in these landscapes. Sediment yields in the suburban and urban Upper Difficult Run are among the highest ever recorded in the Chesapeake Bay watershed, ranging from 161 to $376 \mathrm{Mg} / \mathrm{km}^{2} / \mathrm{y}$. Erosion and deposition of streambanks, channel bed, and bars and deposition of floodplains were monitored between 1 March 2010 and 18 January 2013 in Upper Difficult Run, Virginia, USA. We documented the effects of two large storms, Tropical Storm Lee (September 2011), a 100-year event, and Super Storm Sandy (October 2012) a 5-year event, on channel erosion and deposition. Variability in erosion and deposition rates for all geomorphic features, temporally and spatially, are important conclusions of this study. Tropical Storm Lee was an erosive event, where erosion occurred on $82 \%$ of all streambanks and where $88 \%$ of streambanks that were aggrading before Tropical Storm Lee became erosional. Statistical analysis indicated that drainage area explains linear changes $(\mathrm{cm} / \mathrm{y})$ in eroding streambanks and that channel top width explains cross-sectional area changes $\left(\mathrm{cm}^{2} / \mathrm{y}\right)$ in eroding streambanks and floodplain deposition $(\mathrm{mm} / \mathrm{y})$. A quasi-sediment budget constructed for the study period using the streambanks, channel bed, channel bars, and floodplain measurements underestimated the measured suspended-sediment load by $61 \%$ (2130 Mg/y). Underestimation of the sediment load may be caused by measurement errors and to contributions from upland sediment sources, which were not measured but estimated at $36 \%$ of the gross input of sediment. Eroding streambanks contributed $42 \%$ of the gross input of sediment and accounted for $70 \%$ of the measured suspended-sediment load. Similar to other urban watersheds, the large percentage of impervious area in Difficult Run and direct runoff of precipitation leads to increased streamflow and streambank erosion. This study emphasizes the importance of streambanks in urban-suburban sediment budgets but also suggests that other sediment sources, such as upland sources, which were not measured in this study, can be an important source of sediment.
\end{abstract}




\section{Introduction}

Fine sediment is a major pollutant degrading aquatic ecosystems worldwide through light attenuation, burial, and pollutants sorbed onto sediment. In the Chesapeake Bay watershed, sediment has been shown to be a major pollutant affecting stream habitat (Langland et al., 2003). In order to effectively manage sediment, determining the sources of sediment and locations in a watershed where erosion and storage of sediment are occurring is important. Currently, models to estimate sediment loadings and sources in the Chesapeake Bay do not specifically identify streambank erosion (Brakebill et al., 2010; USEPA, 2010). Furthermore, determining the contribution of streambank erosion in a watershed budget is important for management strategies aimed at reducing erosion, as well as to provide information for sediment processes and model development.

Several watersheds in the Chesapeake Bay watershed are being studied to understand nutrient and sediment processes (Gellis and Brakebill, 2013). Difficult Run, Virginia, is one of these watersheds, where one of the objectives is to develop sediment budgets to understand the sources, storage, and delivery of sediment. Difficult Run is also a watershed where Fairfax County, Virginia, is seeking to reduce sediment and nutrient loads through restoration efforts in the watershed. As part of the restoration effort, Difficult Run is being monitored for sediment loads, streambank erosion, channel change, and floodplain deposition. This paper examines channel (streambank, floodplain, and channel bed and bar) changes between 2010 and 2013 in the upper reaches of Difficult Run (herein referred to as UDR). Results are presented as a sediment budget relative to sediment loads; upland erosion was not measured and is determined as the residual from the sediment budget. Trimble (1997) used a similar approach using streambank measurements and estimating upland contributions for an urban sediment budget in San Diego Creek, California. Channel erosion and deposition measurements made in watersheds that are dominantly urban are limited, for the Chesapeake Bay and worldwide (Table 1). With the occurrence of two major storms during the study period, Tropical Storm Lee on 8 September 2011 and Super Storm Sandy on 29-30 October 2012, the opportunity presented itself to determine how large storms affect geomorphic processes of erosion and deposition in an urban-suburban watershed.

\subsection{Background}

The UDR drains an urban-suburban area in northern Virginia (VA), just outside of Washington D.C., in the Piedmont Physiographic Province. The Piedmont Physiographic Province of the Chesapeake Bay watershed experienced land-use conversion from forest to agriculture in the 
eighteenth and nineteenth centuries (Jacobson and Coleman, 1986; Gellis et al., 2003).

Sediment generated from historic agricultural practices (Jacobson and Coleman, 1986) along with the construction of numerous mill ponds (Walter and Merritts, 2008) led to sediment accumulation on floodplains. Additional sediment generated during suburban housing construction, such as in the Difficult Run watershed in the mid-twentieth century, also increased erosion and accumulation of sediment on floodplains and channels (Wolman, 1967). The historic sediment generated from agriculture and urbanization, referred to as legacy sediment, is presently observed in Difficult Run as a stratigraphic unit overlying an older precolonial soil (Hupp et al., 2013). The Piedmont Physiographic Province also has the highest sediment yields of any physiographic province in the Chesapeake Bay watershed (Gellis et al., 2009).

\subsection{Tropical Storm Lee and Super Storm Sandy}

Tropical Storm Lee (TS Lee) made landfall in Louisiana on 3 September 2011 and traveled up the northeast coast impacting the UDR watershed on 8 September 2011 (Brown, 2011). Local newspapers described the intense rains and flooding (Weil, 2011), where the rainfall total for Fairfax County, VA, was 10.29 inches (261 mm; Brown, 2011). Rain gages in Fairfax County, VA: the Kingstowne rain gage (38.75194 N, 77.15555 W) $20 \mathrm{~km}$ from the study watershed, recorded 5.47 inches $(139 \mathrm{~mm})$ in 3 hours, a 500 -year rainfall; and the Fort Belvoir rain gage $(38.71492 \mathrm{~N}, 77.18089 \mathrm{~W}) 23 \mathrm{~km}$ from the study watershed recorded $7.03(178 \mathrm{~mm})$ inches in 3 hours, a 1000-year rainfall (U.S. Department of Commerce, 2011). Peak flow recorded at a USGS gage serving UDR, Difficult Run above Fox Lake, VA (Fig. 1; USGS station ID 01645704), was $110 \mathrm{~m}^{3} / \mathrm{s}$. The USGS streamflow gage located downstream from UDR on Difficult Run near Great Falls, VA (Fig. 1; USGS station ID 01646000), which has a longer period of record going back to 1935, recorded a peak flow of $481 \mathrm{~m}^{3} / \mathrm{s}$; estimated to be an event with a recurrence interval between 100 and 200 years (Austin et al., 2011).

Super Storm Sandy (SS Sandy) was a late-season hurricane in the southwestern Caribbean Sea that traveled up the southeastern coast of the United States, turning northwest toward the mid-Atlantic states and eventually making landfall again in New Jersey and New York (Blake et al., 2013). Super Storm Sandy had the greatest number of fatalities from a mid-Atlantic storm since Hurricane Agnes in 1972 (Blake et al., 2013). Super Storm Sandy impacted the Difficult Run Watershed on October 29-30, 2012. Rainfall total for Fairfax County, VA, was 6.25 inches (159 mm; Blake et al., 2013). Difficult Run at Fox Lake recorded a peak flow of $44.5 \mathrm{~m}^{3} / \mathrm{s}$, and Difficult Run near Great Falls recorded a peak flow of $75.0 \mathrm{~m}^{3} / \mathrm{s}$ - estimated to be an event at Great Falls with a recurrence interval between 2 and 5 years (Austin et al., 2011).

\section{Setting}

The UDR is defined here as a fifth-order stream in the crystalline Piedmont (gneiss and schist bedrock) of Virginia that is a tributary to the Potomac River and the Chesapeake Bay (Fig. 1; Schenk et al; , 2012). Drainage area of UDR above the stream gage (USGS station ID 01645704 ) is $14.2 \mathrm{~km}^{2}$ (Fig. 1). Most portions of UDR are meandering, pool-riffle systems on gravel to sand beds with occasional bedrock outcrops. Well-developed sand and gravel point 
bars are also common in second- to fifth-order channels. Fine-grained channel deposits can be found in all stream reaches. Many of the streams in UDR are deep, narrow channels incised below the former floodplain that is now a terrace, located several meters above the channel bed. Channel width:depth ratios are <6.0 (Table 2) where Rosgen (1994) described channels with width:depth ratios $<12$ as incised. A forested riparian buffer is common in most reaches, with roads, lawns, and other infrastructure buffering the channel along many reaches. Mean annual streamflow recorded at the site from 2008 through 2013 is $0.25 \mathrm{~m}^{3} / \mathrm{s}$.

Average annual rainfall recorded at Vienna, Virginia (Fig. 1), from 1943 through 2011, located $\sim 6 \mathrm{~km}$ from UDR is $1098 \mathrm{~mm} /$ year. The average sediment yield for UDR computed using suspended sediment collected at the UDR gage from 2008 through 2013 was $295 \mathrm{Mg} / \mathrm{km}^{2} / \mathrm{y}$ (Jastram, 2014), which is the second highest sediment yield from studies in the Washington D.C. area reported after 2000 (Fig. 2).

Fairfax County, Virginia is currently one of the most urbanized areas in the United States. In 2014, the population was 1,116,246 or 1059 persons per square kilometer (Khaja et al., 2014). The number of persons per square kilometer in 1970 was 436, more than doubling to 999 in 2004 (Kiely et al., 2006 ). By 2009, 327,319 housing units were built in Fairfax County with 75\% of these units constructed by 1989 (Maliszewski, 2014). By 2004, only $9 \%$ of the county was in nondeveloped land (Kiely et al., 2006). In 2011, land use in the basin was $27 \%$ low intensity residential, 26 high intensity developed, and 46\% forest (Homer et al., 2015). Twenty-three percent of the basin is characterized as impervious (Xian et al., 2011). All sampling reaches in UDR contain urban areas, albeit highly variable throughout the watershed (Fig. 3).

\section{Methods}

Twenty-four reaches in UDR were monitored to determine changes in streambank erosion and deposition (Fig. 1; Table 2). At 13 of the 24 reaches, one or more full cross section surveys were monumented to measure, in addition to streambanks, changes of the channel bed, channel bars, and floodplain. Sites were chosen after a reconnaissance of the basin to provide a good spatial representation of channel geomorphic conditions.

\subsection{Streambanks}

One-hundred and forty banks were monitored for erosion and deposition in 24 reaches between 1 March 2010 and 18 January 2013. Erosion and deposition of streambanks were monitored for four time periods with TS Lee occurring between the first resurvey and second resurvey and with SS Sandy occurring between the third resurvey and the fourth resurvey (Fig. 4).

At each of the 24 reaches, streambanks on both sides of the channel were selected to monitor erosion and deposition. Streambank selection was based on inspection of the reach $(\sim 100 \mathrm{~m}$ length) to obtain representative streambanks. Streambanks for monitoring were generally spaced at least two channel widths apart. On each streambank face, two to five, $1.2 \mathrm{~m}$ long, 1.9 $\mathrm{cm}$ diameter steel pins were inserted in the bank. The number of pins installed in the bank, which ranged from 2 to 5, was based on the height of the bank. For the higher banks, installing more than 5 pins was deemed to cause additional disturbance. The portion of the pins 
protruding out of the streambank were measured on installation and then measured over time to determine whether the streambank was eroding or depositing. In areas of high erosion, pins may be lost if not read frequently. Streambank pins were read close to one year and after major storm events. Channel surveys were typically performed only after a major storm event. This resulted in more streambank and bar measurements after installation than floodplain and bed measurements. In cases where two or more pins were missing, measurements were not taken and the missing pins were replaced. If this occurred on the final measurement, that bank face was not used in the analysis. The number of streambanks measured for each survey period therefore varied.

For discussion purposes, changes in streambanks are shown between surveys, termed gross changes, and for the entire study period, termed net changes. For each bank face: (i) a gross average linear change $(\mathrm{cm})$ is determined as the difference in each pin from the previous survey and averaged for the bank face, and (ii) a gross cross-sectional area change $\left(\mathrm{cm}^{2}\right)$ where the average linear change for each bank face is multiplied by the height of the bank. Positive values indicate erosion, and negative values indicate deposition. It is possible that a linear change can show erosion and that the cross-sectional area change can show deposition. This occurs when the streambanks are higher for depositing banks than for eroding banks.

Changes in streambanks are presented for individual streambanks and by reach. A reachaveraged streambank change $\left(\mathrm{cm}\right.$ or $\left.\mathrm{cm}^{2}\right)$ is the average of all streambanks in a reach. It is common in the literature to display streambank change as an annual rate $\left(\mathrm{cm} / \mathrm{y} ; \mathrm{cm}^{2} / \mathrm{y}\right.$; Leopold et al., 1966; Kelsey, 1980; Gellis et al., 2012). Because measurement periods varied (Fig. 4), the total change in a channel feature (streambank, channel bed, bar, floodplain) was divided by the number of days between measurements and multiplied by 365.25 to get an annual rate.

Freeze-thaw activity can also be an important process in streambank erosion (Wolman, 1959; Wynn, 2006). To determine if the rates of streambank change were related to freeze-thaw activity, minimum and maximum daily temperature data was obtained from the weather service station Vienna, VA (NOAA, 2014) located $\sim 6 \mathrm{~km}$ east of the Difficult Run above Fox Lake gage. A freeze-thaw day is defined where the temperature fell above and below freezing. The total number of freeze-thaw days was determined between each streambank pin resurvey and then normalized by the number of days between each measurement period. This normalized freezethaw value was then compared to the rates of streambank change for all measurement periods to determine if freeze-thaw is an important process in eroding streambanks. We recognize that this approach is unlikely to provide precise assessment of streambank erosion, but it should provide a useful metric for comparing freeze-thaw potential for the different monitoring periods.

\subsection{Changes in the channel bed, floodplain, and bars}

Resources allowed us to perform full cross-sectional surveys at only 13 of the 24 reaches where changes in the channel bed and floodplain were monitored over time (Table 2). The 13 reaches were selected based on geomorphic features (bank height, bank angle, land use, sinuosity, etc.) that were considered representative of the UDR watershed. Cross sections were established 
between $6 / 15$ and $9 / 27 / 2010$. Endpoints of the cross section were monumented with metal pins that were used to maintain elevation control through resurveys. Surveys were conducted using a laser level. Cross sections were resurveyed twice, between 9/20-11/30/2011 and 12/17/20121/18/2013 (Fig. 4).

Floodplain deposition (top surface of the floodplain) was monitored with powdered white feldspar clay $\sim 20 \mathrm{~mm}$ in thickness that were placed over an area of about $0.5 \mathrm{~m}^{2}$ on the soil surface that had been cleared of organic detritus (Hupp and Bazemore, 1993). The clay becomes a fixed plastic marker after absorption of soil moisture that permits measurement of vertical accretion above the clay surface. Clay pads were installed between 15 June 2010 and 17 August 2010 and read 3 times during the study period (Fig. 4). At each reading the clay marker layer was found by cutting into the soil and measuring the depth of deposited sediment above the clay while trying to keep disturbance to a minimum. The clay marker was left in place and located again in subsequent measurements. If the floodplain is aggrading through time the readings should be increasing. A negative difference between surveys could indicate erosion of the floodplain or that it was disturbed between readings. Because it is not possible to conclude whether erosion or disturbance is the cause, negative readings were given a value of zero. All pads in the cross section were averaged to obtain an average floodplain deposition. If a pad could not be found on the final measurement, it was not used to obtain a study period deposition rate and other pads in the cross section were used to determine the average floodplain deposition. The average floodplain deposition for a cross section was multiplied by the width of the floodplain to obtain a cross-sectional area change $\left(\mathrm{m}^{2}\right)$. The floodplain width was based on geomorphic features of topography, vegetation, and soil characteristics and was determined for the monitoring reach by using a hand tape and averaging the width at various portions along the reach.

Most bars in UDR can be described as point bars, mid-channel bars, and longitudinal bars (Hooke and Yorke, 2011). Twenty-two bars in 12 of the 24 reaches were monitored between 1 March 2010 and 18 January 2013 with installation of pins to monitor bar changes between 1 March 2010 and 30 August 2010. Erosion and deposition of bars were monitored for 4 time periods (Fig. 4). If a cross section contained a bar, erosion and deposition of the bar were determined using steel pins, where 1 to 5 pins, each $1.2 \mathrm{~m}$ long and $1.9 \mathrm{~cm}$ in diameter, were inserted in the bar along the survey cross section and measured over time. The erosion and deposition of the bar $(\mathrm{cm} / \mathrm{y})$ is the average of all pins $(\mathrm{cm})$, divided by the number of days and multiplied by 365.25 .

\subsection{Statistical analysis for the resurvey periods}

Changes in streambanks, channel bed, channel bars, and floodplains were analyzed for differences in rates between survey periods, with specific interest in examining the effects of two large storms, TS Lee and SS Sandy (Table 3). The Mann-Whitney rank sum test $(p<0.05)$ was used to test significant differences in the median values of streambank, channel bed, channel bar, and floodplain changes for various time periods and for different stream orders. 
Streambanks were tested for differences in linear $(\mathrm{cm} / \mathrm{y})$ and cross-sectional area changes $\left(\mathrm{cm}^{2} / \mathrm{y}\right)$ for (i) gross reach-averaged changes, (ii) gross changes for all streambanks (erosion and deposition), (iii) gross changes at all depositing streambanks, and (iv) gross changes at all eroding streambanks (Table 3). Gross reach averaged and gross cross section changes at channel bars and gross cross-sectional floodplain changes were also tested for changes between survey periods. Differences in rates by stream order for streambanks (separated into all, aggrading, and eroding), all bars, all streambeds, and all floodplains were tested using a Mann Whitney rank sum test.

\subsection{Analysis of variables to understand streambank change}

Variables used in the statistical analysis of streambank change can be categorized as follows: cross-sectional and longitudinal characteristics; flow parameters; temperature conditions (primarily the influence of freeze and thaw); vegetation cover; and channel bank material. Nine variables were tested in this study against streambank change $\left(\mathrm{cm} / \mathrm{y}\right.$ and $\mathrm{cm}^{2} / \mathrm{y}$ ): (i) drainage area, (ii) streambank angle, (iii) floodplain width, (iv) bank height, (v) active channel-bed width, (vi) top width, (vii) top width to bank height ratio, (viii) percent fines (silt and clay) of the streambanks, and (ix) the portion (\%) of impervious cover in the contributing area to each study reach (Table 2). Channel variables (top width, bank height, active channel-bed width, bank angle, and floodplain width) were obtained from the 13 reaches where channel cross section surveys using a laser level were performed. For 10 sites, a tape and inclinometer and not a laser level were used to determine these channel variables. The nine variables used in statistical analysis are: (i) Floodplain width, if present, was determined as the horizontal distance from the top of the channel bank to the base of the terrace or hillslope scarp; (ii) bank height was measured vertically from the top to the bottom of the bank; (iii) bank angle is the angle of the channel bank, in degrees; (iv) Top width was measured horizontally from the top of each bank; (v) Top width to channel depth ratio; (vi) Active channel-bed width is measured along the channel bed between both banks and can include bars; (vii) Percent fines is the percent of streambank material that passes through a $63-\mu \mathrm{m}$ sieve to determine the percent of silt and clay. Analysis of fines was performed using wet sieving through a $63-\mu m$ sieve; (viii) Drainage area (Homer, 2015); and (ix) the impervious cover contributing to each reach (Xian et al., 2011) were derived from a geographic information system (GIS).

The nine explanatory variables were tested against the response variable, net reach-averaged streambank change (all streambanks including erosion and deposition; $\mathrm{cm} / \mathrm{y}$ and $\mathrm{cm}^{2} / \mathrm{y}$ ) using forward stepwise regression. Because the literature often shows statistical analysis only with eroding streambanks, only those banks that showed erosion were also used in the statistical analysis. The number of aggrading streambanks was too small to test as a separate group ( $\mathrm{cm} / \mathrm{y} ; \mathrm{n}=4$ and $\left.\mathrm{cm}^{2} / \mathrm{y} ; \mathrm{n}=6\right)$. Because bank height is used in the computation of streambank cross-sectional area change, bank height was not included as an explanatory variable when streambank cross-sectional area was the response variable.

The set of explanatory variables for the regression model was selected using forward stepwise regression procedures in the statistical software package SAS (SAS Institute, 2008*). Variables 
selected in the model were then tested to determine if the regression was significant. A significant regression is defined as the slope of the line-of-best fit with a $p$-value $<0.05$, and the residuals are normally distributed with a Shapiro-Wilk test value $>0.05$ (Helsel and Hirsch, 1992). If the explanatory and response variables did not meet these criteria, the data were tested using a Shapiro-Wilk test $(p>0.5)$ for a log-normal distribution and if necessary transformed. If after log-transformation a significant regression was still not met, variables were transformed using either an inverse, squared, square root, or cube root transform; and each was tested for a significant regression (Helsel and Hirsch, 1992). Impervious cover and fines that are percentages were only transformed using the arcsine

-square root transformation. To avoid multicollinearity, after variables were transformed a correlation matrix was used to identify variables with a high correlation $(r>0.70)$ and if necessary variables were removed.

Variables important in reach-averaged floodplain deposition rates include flow (magnitude, frequency, and duration of inundation; Middelkoop and Van Der Perk, 1998); drainage area (Magilligan, 1985); connectivity of flows to the floodplain or bank height (Simm and Walling, 1998); local microtopographical factors (Asselman and Middelkoop, 1995; Simm and Walling, 1998), floodplain width (Magilligan, 1985; Noe and Hupp, 2009; sediment loadings (Middelkoop and Van Der Perk, 1998); and grain size (Lambert and Walling, 1987). All these variables, except for sediment loadings were available at Difficult Run and are similar to the nine variables assembled above to explain streambank change. The nine variables used to explain streambank changes were used to understand reach-averaged floodplain deposition rates $(\mathrm{mm} / \mathrm{y})$. The procedures to determine significant variables explaining deposition rates followed the same procedures as streambank changes.

\section{Sediment Budget}

For the entire study period, a sediment budget was constructed for UDR that uses the erosion and deposition measurements of streambanks, channel beds, channel bars, and floodplains to estimate a mass and compares this mass to the suspended-sediment load exported at the streamflow station, as follows:

$$
\text { I+ } \Delta S=O
$$

$\mathrm{I}=$ input of sediment from channel banks and channel bed and bars (Mg/y);

$\Delta \mathrm{S}=$ change in sediment storage in channel banks, channel bed and bars, and floodplains (Mg/y); and

$\mathrm{O}=$ annual suspended sediment load export at the station Difficult Run at Fox Lake, VA (Fig. 1) for the period of study, March 2010 to January 2013 (Jastram, 2014).

Suspended-sediment load was computed using the software package Load Estimator (SLOADEST; Lorenz et al., 2011) from discrete monthly and storm suspended-sediment samples

* "Any use of trade, firm, or product names is for descriptive purposes only and does not imply endorsement by the U.S.Government." 
as dependent variables and from continuous streamflow, turbidity, and water temperature as explanatory variables (Jastram , 2014).

Upland erosion was not measured in the sediment budget and is presented in the paper as the residual in the sediment budget or the difference in the measured sediment export minus the inputs $(I)$ and storage terms $(\Delta S)$ from the sediment budget.

\subsection{Computation of the sediment budget}

The sediment budget is based on determining volumetric changes in streambanks, channel bed, channel bars, and floodplains and on converting these to a mass using the density of each geomorphic feature. Cross-sectional area changes in streambanks, bars, bed, floodplains $\left(\mathrm{cm}^{2} / \mathrm{y}\right)$ were averaged for each reach and then averaged for each stream order. Channels were classified as first- to fifth- order channels using a GIS. Using stream order to extrapolate channel measurements for the entire watershed is straightforward (Gellis et al., 2015) but does not imply that measurements among the different stream orders are statistically different. The average change of streambanks, floodplains, and the channel bed for each stream order were multiplied by the length of that stream order $(\mathrm{m})$ to obtain a volume $\left(\mathrm{m}^{3} / \mathrm{y}\right)$. Because streambanks are located on both sides of the channel, the volume change for streambanks was multiplied by 2 .

Unlike streambanks and the channel bed, bars are not continuous features but occur intermittent and have varying widths and length. To extrapolate the average linear bar change $(\mathrm{cm} / \mathrm{y})$ measurements at a reach to a volumetric change $\left(\mathrm{cm}^{3} / \mathrm{y}\right)$, a survey was conducted at 13 reaches in UDR to determine the width, length, and frequency of bars that are estimated to be representative of the entire watershed (supplementary Table 1). At each of the 13 reaches, a tape was laid out longitudinally along the channel reach, and the length of each bar was noted. The length of the tape used in the surveys for first- and second- order channels was 50 to $63 \mathrm{~m}$ (except for Site R12 which was 200m), and in third-, fourth-, and fifth- order channels, the length of the tape was 100 to $200 \mathrm{~m}$ (supplementary Table 1).

The volumetric change in bars $\left(\mathrm{cm}^{3} / \mathrm{y}\right)$ for each stream order was determined as follows:

$$
\text { Reachbarper }(i)=\text { Reachbarlen }(i) / \operatorname{tapelen}(i) * 100
$$

Reachbar $_{\text {per(i) }}$ is the percent length of the reach $i$ that contains bars;

Readbar $_{\text {len(i) }}$ is the total length of bars measured in reach $\mathrm{i}(\mathrm{m})$; and

Tape $_{\text {Ien(i) }}=$ length of tape $(\mathrm{m})$ used in bar survey at reach $\mathrm{i}$.

$$
\operatorname{Stordbar}(\mathrm{j})=n i \operatorname{Reachbarper}(\mathrm{i})(\mathrm{j})(\mathrm{nj}) x \operatorname{Strlen}(j)
$$

Stord $_{\text {bar(j) }}$ is the length of stream order $\mathrm{j}$ that contains bars, in percent; Reachbar $_{\text {per(i)(j) }}$ is the length of the reach $\mathrm{i}$, in stream order $\mathrm{j}$, that contains bars, in percent; $n_{j}$ is the total number of reaches (i) measured for stream order $\mathrm{j}$; and $\mathrm{Str}_{\text {len(j) }}$ is the length of stream order $\mathrm{j}(\mathrm{m})$, determined with a GIS. 


$$
\text { Barwidj=nibarwid }(i)(j) n j
$$

$B a r_{\text {wid(j) }}$ is the average bar width $(\mathrm{m})$ for stream order $\mathrm{j}$; and $B a r_{\text {widi) }}$ is the average bar width $(\mathrm{m})$ for reach $\mathrm{i}$ in stream order $\mathrm{j}$.

(5)

$$
\operatorname{Barch}(j)=n i \operatorname{Barch}(i)(j)_{n j}
$$

$B a r_{c h(j)}=$ measured bar change for stream order $\mathrm{j}(\mathrm{cm} / \mathrm{y}) ;$ and

$B a r_{c h(i)}=$ measured bar change for reach $\mathrm{i}$, in stream order $\mathrm{j}(\mathrm{cm} / \mathrm{y})$.

$$
(\operatorname{Barvol}(\mathrm{j})=\operatorname{Barwid}(\mathrm{j}) \times \text { Stordbarj } \times \operatorname{Barch}(\mathrm{j}))
$$

$\operatorname{Bar}_{\text {vol(j) }}=$ total volumetric change in bars at stream order $\mathrm{j}\left(\mathrm{cm}^{3} / \mathrm{y}\right)$.

The volumetric change for each geomorphic feature (banks, floodplains, bars, bed) was multiplied by the average bulk density of material for that feature $\left(\mathrm{g} / \mathrm{cm}^{3}\right)$ to obtain a mass $(\mathrm{Mg} / \mathrm{y})$. The density of bank material was obtained using PVC cores of length $6.6 \mathrm{~cm}$ and diameter $4.3 \mathrm{~cm}$, driven flush into the streambanks. Density measurements were made for each cross section, which usually included both bank faces. Bars were cored with $9 \mathrm{~cm}$ length, $10 \mathrm{~cm}$ width PVC. Density measurements were generally made for each bar in a study reach. All density samples were dried at $60^{\circ} \mathrm{C}$ for 48 hours, or until dry, and weighed. A floodplain density of $0.8 \mathrm{~g} / \mathrm{cm}^{3}$ was obtained from Schenk et al. (2012) and used for all floodplains. The mass of sediment deposited or eroded for each geomorphic element was summed by stream order and the mass for all stream orders was totaled (Mg/y).

The total suspended-sediment transported at the gage for the same time period as the sediment budget measurements (March 2010 to January 2013), was divided by the total number of days (1068) and multiplied by 365.25 to obtain an annual mass (Mg/y). This is the export of sediment ( $\mathrm{O}$ in Eq. 1). The total mass of sediment determined from the sediment budget (Mg/y) was compared to the annual export of suspended-sediment (Mg/y) to determine how well the sediment budget was able to estimate sediment flux.

\section{Results}

Changes in streambanks, channel bed and bars, and floodplains for 24 reaches of UDR during the period, March 1, 2010 through January 18, 2013 are presented by stream order, by reach, and for each measurement period (Tables 3,4).

\subsection{Streambank changes}

Streambank changes were analyzed from 492 pins installed on 140 streambanks for 24 reaches of UDR (supplementary Table 2A). The net change for all 140 streambanks was erosion of 2.0 
$\mathrm{cm} / \mathrm{y} \pm 5.2 \mathrm{~cm} / \mathrm{y} ;\left(354 \mathrm{~cm}^{2} / \mathrm{y} \pm 904 \mathrm{~cm}^{2} / \mathrm{y}\right)$ - values that are similar to other studies (Table 1). The majority of the 140 streambanks $(n=109 ; 78 \%)$ showed erosion, and 31 streambanks $(22 \%)$ showed net deposition (Figs. 5A,B). Fourth-order streambanks $(n=24)$ had the highest average erosion rate of $4.2 \pm 7.8 \mathrm{~cm} / \mathrm{y}$ and cross sectional area change of $716 \pm 1391 \mathrm{~cm}^{2} / \mathrm{y}$ (Fig. 5A). The highest cross-sectional area change for any streambank was $5400 \mathrm{~cm}^{2} / \mathrm{y}$ at a fourth- order channel (Fig. 5C; site R31). Net reach streambank change (Table 4) showed overall erosion of $1.5 \pm 2.2 \mathrm{~cm} / \mathrm{y}\left(241 \pm 397 \mathrm{~cm}^{2} / \mathrm{y}\right)$. Fourth-order reaches had the highest rates of streambank erosion (4.0 $\pm 4.0 \mathrm{~cm} / \mathrm{y} ; 659 \pm 750 \mathrm{~cm}^{2} / \mathrm{y}$; Table 4). A Mann-Whitney rank sum test did not show a statistically significant difference in the median values of linear and crosssectional streambank changes (for all streambanks) among the different stream orders (supplementary Table 3B). When separated into aggrading banks, significant differences were found between combined fourth- and fifth-order streambanks and first-, second-, and third- order streambanks (supplementary Table 3C). Eroding streambanks showed differences between first- order and fourth-, and fifth order streambanks (supplementary Table 3D).

\subsection{Streambank changes before and after storms}

Erosion and deposition of streambanks were monitored for four time periods with TS Lee occurring between the first resurvey and second resurvey and SS Sandy occurring between the third resurvey and the fourth resurvey (Fig. 4; supplementary Table 2A). The highest peak flow $\left(110 \mathrm{~m}^{3} / \mathrm{s}\right)$ for the period of study occurred on 8 September 2011 during TS Lee (Table 5). This was the second highest peak flow on record since measurements began at UDR in 2007. The peak flow for SS Sandy on 30 October 2012 was $44.5 \mathrm{~m}^{3} / \mathrm{s}$, the fourth highest peak on record (Table 5). Mean daily discharge was highest for the measurement period following SS Sandy and second highest for the measurement period following TS Lee (Table 5).

For the study period, March 2010 through January 2013, a total of 10,050 Mg of suspended sediment was transported out of the watershed or $3500 \mathrm{Mg} / \mathrm{y}$. September 2010, the month in which TS Lee occurred, had the highest suspended-sediment load (5660 Mg) for any month during the study period, which accounted for $56 \%$ of the total suspended-sediment load for the study period (Table 5). Super Storm Sandy occurred in October 2012 and transported 1320 $\mathrm{Mg}$, which was $13 \%$ of total suspended-sediment load for the study period. The second measurement period, which contained TS Lee, had the highest mean daily suspended-sediment load (Table 5).

Streambank measurements during the study period showed that streambanks alternated between erosion and deposition (Fig. 6). Only 11\% (15 of 140) and 4\% (5 of 140) of streambanks remained erosional or depositional, respectively, through all four resurveys. Tropical Storm Lee was an erosive event, with 115 of the 140 measured streambanks (82\%) showing erosion. Of the streambanks that were eroding before TS Lee $(n=68), 85 \%$ continued to erode after TS Lee. Of the streambanks that were aggrading before TS Lee $(n=58), 88 \%$ switched to erosion (Fig. 6A). For resurvey 3, (post-TS Lee to pre-SS Sandy), approximately half of all 139 measured streambanks (52\%) showed erosion and $48 \%$ showed deposition. Of the streambanks that were eroding after TS Lee $(n=116), 51 \%$ continued to erode; and for streambanks that were aggrading after TS Lee $(n=23), 39 \%$ continued to aggrade (Fig. 6B). For streambank changes after SS Sandy (resurvey 4), 58\% of the 134 measured streambanks showed erosion and $42 \%$ showed deposition. Of the streambanks that were eroding before SS 
Sandy $(n=71), 51 \%$ continued to erode and of the streambanks that were aggrading $(n=62)$, $32 \%$ continued to aggrade (Fig. 6C).

Streambank changes by reach showed gross erosion in 21 reaches after TS Lee, with 3 reaches showing gross deposition. Following SS Sandy, 14 reaches showed gross erosion with 10 showing gross deposition. Averaging all the reach changes showed that the period after TS Lee had the highest gross erosion rate $\left(4.6 \pm 4.4 \mathrm{~cm} / \mathrm{y} ; 686 \pm 1014 \mathrm{~cm}^{2} / \mathrm{y}\right.$; Fig. 7A,B; supplementary Table $2 \mathrm{~B})$. The greatest change in cross-sectional area for any reach occurred after SS Sandy was at reach R28 $\left(3770 \mathrm{~cm}^{2} / \mathrm{y}\right)$ and at reach $\mathrm{R} 8\left(-1120 \mathrm{~cm}^{2} / \mathrm{y}\right)$, respectively (supplementary Table 2B).

A Mann-Whitney rank sum test comparing the gross reach streambank changes (erosion and deposition; $\mathrm{cm} / \mathrm{y}$ and $\mathrm{cm}^{2} / \mathrm{y}$ ) between surveys indicated that the differences between the first and second surveys and between the second and third surveys were significant (supplementary Table 3A). Tropical Storm Lee occurred between the first and the second measurement periods and is likely the reason for the large differences in streambank rates between these periods. Gross reach streambank changes before and after SS Sandy did not show significant changes (supplementary Table 3A). Analyzing changes by individual streambanks (for erosion and deposition and just for eroding) also showed a significant difference in rates (cm/y and $\left.\mathrm{cm}^{2} / \mathrm{y}\right)$ before and after TS Lee; with eroding banks showing significant results for all periods (supplementary Tables 3B,D). Aggrading streambanks only showed significant differences before and after SS Sandy (supplementary Table 3C).

Daily changes in freeze and thaw can also be an important mechanism in eroding streambanks (Pizzuto and O'Neal, 2010). The highest erosion rates occurred between the first and second surveys when TS Lee occurred (Fig. 7). This period did not show the greatest number of freezethaw days normalized by the number of days between measurements (Fig. 8A). The highest number of normalized freeze thaw days occurred between the third and fourth resurveys (24 October 2012 to 2 March 2013; Fig. 8A), and freeze-thaw may have been a factor contributing to this period having the second highest rates of streambank erosion (Fig. 7) as well as the highest recorded erosion rate for a given reach (R28; supplementary Table 2B). Plots of freezethaw days vs. streambank changes $\left(\mathrm{cm} / \mathrm{y}\right.$ and $\mathrm{cm}^{2} / \mathrm{y}$ ) do not show a significant relation (Figs. $8 \mathrm{~B}, \mathrm{C})$. Although freeze-thaw does not appear to be the dominant mechanism causing the higher rates of streambank erosion in UDR, we cannot determine conclusively that it is not a contributing factor to streambank erosion. A program of measuring streambank changes on a more frequent basis, daily or weekly, could provide information on the relative difference between storm-generated bank erosion and freeze-thaw activity.

\subsection{Bar changes}

Twenty-two bars were measured in 11 reaches during the period of study. The net linear change (erosion and deposition) of all bars (not reach averaged) for the study period was erosion of $0.3 \pm 3.7 \mathrm{~cm} / \mathrm{y}$ (supplementary Table 4). The percent of all bars showing erosion through each of the four surveys varied from (resurvey 1) $45 \%$, to (resurvey 2 ) $45 \%$, to (resurvey 3 ) $41 \%$, to (resurvey 4) $54 \%$ - with $50 \%$ of all bars showing net erosion for the study period. The largest average change for all bars (not reach averaged) was observed after SS Sandy, with an erosion rate of $13.5 \pm 35.0 \mathrm{~cm} / \mathrm{y}$ (Fig. 9A). 
Similar to changes in streambanks, bar changes over the 4 measurement periods were highly variable, with only 1 bar showing erosion and one bar showing deposition through all four measurements (Supplemental Table 4). Reach-averaged changes showed the period after SS Sandy with the highest rate of erosion in bars $(9.8 \pm 22.2 \mathrm{~cm} / \mathrm{y}$; Fig. 9B; Table 4). Results of the Mann-Whitney rank sum test showed significant differences before and after SS Sandy for gross reach-averaged changes (supplementary Table 3E) and gross eroding bars (supplementary Table $3 \mathrm{H}$ ). Significant results were not observed when examining bar changes by stream order (supplementary Tables 3F, G, H).

\subsection{Channel bed changes}

Thirty-nine cross sections in 13 reaches were surveyed over time to examine changes in the channel bed (Figs. 4, 10A; supplementary Table 5). For the period of study, changes in the channel beds ranged from erosion of $0.15 \mathrm{~m}^{2} / \mathrm{y}$ to deposition of $0.60 \mathrm{~m}^{2} / \mathrm{y}$, averaging a net of zero change $\left(0.00 \pm 0.10 \mathrm{~m}^{2} / \mathrm{y}\right)$ (Fig. 10A). Sixty-one percent of cross sections surveyed after TS Lee showed erosion with an average of $0.02 \pm 0.18 \mathrm{~m}^{2} / \mathrm{y}$ (Fig. 10A). Fifty percent of channel beds surveyed after SS Sandy showed deposition (-0.01 $\left.\pm 0.10 \mathrm{~m}^{2} / \mathrm{y}\right)$ (Fig. 10A). Averaging bed changes by reach, showed that second order reaches had the highest rate of erosion $(0.021 \pm$ $\left.0.039 \mathrm{~m}^{2} / \mathrm{y}\right)$ and a fifth order reach had the greatest deposition $\left(-0.16 \mathrm{~m}^{2} / \mathrm{y}\right)(\mathrm{Fig} .10 \mathrm{~b}$; supplementary Table 5). Bed changes did not show any statistical differences between survey periods or between stream orders (supplementary Table 3I).

\subsection{Floodplain deposition}

Deposition was recorded on 35 floodplain cross sections for 13 reaches during the period of study (supplementary Table 6). Floodplain deposition was measured 3 times where the second measurement occurred after TS Lee and the third measurement occurred after SS Sandy (Fig. 4). Net deposition for all floodplain cross sections was $3.2 \mathrm{~mm} / \mathrm{y} \pm 4.5$, ranging from 0 to 16.0 $\mathrm{mm} / \mathrm{y}$ - values that are similar to other studies (Table 1). Net reach floodplain deposition rates showed deposition of $3.2 \pm 3.5 \mathrm{~mm} / \mathrm{y}$. The highest reach-average deposition rate was for a fifth

order floodplain (9.6 mm/y; site R35; supplementary Table 6). A Mann-Whitney test examining differences by stream order showed deposition rates between first and combined fourth and fifth order floodplains and between second and combined fourth and fifth order floodplains were significant (supplementary Table 3J).

Deposition rates varied through the three surveys and showed that the greatest floodplain deposition occurred after TS Lee (average deposition of $5.9 \pm 12 \mathrm{~mm} / \mathrm{y}$; Fig. 11A). In the first measurement, $24 \%$ of floodplain cross sections recorded $>1 \mathrm{~mm}$ up to $6 \mathrm{~mm}$ of deposition (Fig. 11B). After TS Lee, $31 \%$ of all floodplain cross sections recorded $>1 \mathrm{~mm}$ up to $29 \mathrm{~mm}$ of 
deposition (Fig. 11B). After SS Sandy, 46\% of floodplain cross sections recorded $>1 \mathrm{~mm}$ up to $32 \mathrm{~mm}$ of deposition (Fig. 11B). A Mann-Whitney rank sum test showed that the difference in floodplain deposition rates (not reach averaged; $\mathrm{mm} / \mathrm{y}$ ) between the first survey and the survey after TS lee (second survey) were significant for cross section floodplain changes

(supplementary Table 3K). Reach-averaged floodplain deposition rates were not significantly different between survey periods (supplementary Table $3 \mathrm{~L}$ ).

\subsection{Statistical analysis of variables predicting streambank erosion and floodplain sedimentation}

Forward stepwise regression was conducted to determine which variables can best predict linear $(\mathrm{cm} / \mathrm{y})$ and cross-sectional area $\left(\mathrm{cm}^{2} / \mathrm{y}\right)$ streambank changes (deposition and erosion), as well as for streambanks that only showed erosion. A correlation matrix examining correlations among these nine variables used in forward stepwise regression indicated that the activechannel bed width and channel top width were correlated in all models (supplementary Table 7) and the active-channel bed width was removed. Log drainage was correlated to log channel top width in two models (all bank changes and eroding banks $\left(\mathrm{cm}^{2} / \mathrm{y}\right)$; supplementary Table 7 ). Because drainage area is used as a surrogate of flow and channel top width is an important geomorphic measurement identified in other studies (Schenk et al., 2012), both variables were left in the forward-stepwise regression model.

Forward-stepwise regression results for all streambank changes did not show any significant variables. Results for linear changes in eroding streambanks (cm/y) showed the log of drainage area as a significant variable in explaining change (Fig. 12; Table 6A). Log channel top width was significant in explaining cross-sectional area changes $\left(\mathrm{cm}^{2} / \mathrm{y}\right)$ of eroding streambanks (Fig. 12; Table 6A).

Results of regression analysis on variables explaining floodplain deposition showed correlations between channel top width and the following: drainage, area, active channel width, and channel width:depth (supplementary Table 7). The active channel width, and channel width:depth were removed. Forward-stepwise regression results indicated channel top width as a significant variable explaining deposition rates (Table 6B).

\subsection{Sediment budget results}

A sediment budget was determined from the measurements made on streambanks, floodplain, channel beds, and channel bars for the study period (Table 4) and compared to suspendedsediment loads at the USGS streamflow station, Difficult Run at Fox Lake, VA (3,500 Mg/y; Table 7). Because only a few measurements were made on floodplains, channel beds, and bars in third order channels, third order changes were computed by averaging rates from other stream orders (Table 4). The sediment budget estimated that $1370 \pm 2620 \mathrm{Mg} / \mathrm{y}$ of sediment was exported from UDR during the study period (Table 7). This underestimated the suspended- 
sediment load at the station by $2,130 \mathrm{Mg} / \mathrm{y}(61 \%$; Table 7$)$ but is within the range of uncertainty. The final sediment budget (Table 7 ) in terms of Eq. 1 is:

$$
5920 \mathrm{Mg} / \mathrm{y}(\mathrm{I})-2420 \mathrm{Mg} / \mathrm{y}(\mathrm{S})=3500 \mathrm{Mg} / \mathrm{y}(\mathrm{O})
$$

Results of the sediment budget using Eq. 2 show that streambanks account for $42 \%$ of the total gross input of sediment, the channel bed accounts for $20 \%$, and channel bars account for $2 \%$. The unmeasured contribution of gross erosion $(2130 \mathrm{Mg} / \mathrm{y})$ was $36 \%$ of the gross input of sediment. This residual or unknown mass of sediment is assumed to come from upland sources in UDR. This could include forests, open space, and residue on roads.

If storage components are ignored, the mass of sediment supplied from eroding streambanks $(2460 \mathrm{Mg} / \mathrm{y})$ was $70 \%$ of the suspended sediment load. First-order streambanks contributed the greatest mass of streambank sediment $1050 \pm 265 \mathrm{Mg} / \mathrm{y}(43 \%$; Table 7). The mass of sediment deposited on floodplains was $1820 \pm 314 \mathrm{Mg} / \mathrm{y}$ (Table 7), which is $75 \%$ of all storage quantified in the sediment budget and $52 \%$ of the total suspended-sediment load. Compared to the other stream orders, fifth and first order floodplains stored the most floodplain sediment, $28 \%$ and $27 \%$, respectively. Channel beds and bars stored $17 \%$ and $8 \%$, respectively, of all stored sediment.

\section{Discussion}

\subsection{Channel change and large storms}

Changes in streambanks in the UDR watershed show that erosion and deposition are highly variable from one survey to the next (Fig. 6), except as a result of TS Lee when most reaches showed erosion (Fig. 7). Only 15 and 5 of the 140 streambanks consistently eroded and aggraded, respectively, through all four measurement periods. Changes in bars $(n=24)$ were also highly variable through the four resurveys, with only one bar showing erosion and one bar showing deposition through all measurements periods (supplementary Table 4). Booth and Henshaw (2001) showed temporal and spatial variability in bank erosion for urban channels in western Washington, USA (drainage areas 0.1 to $20 \mathrm{~km}^{2}$ ), that were related to variability of watershed soil properties, runoff events, seasonality, and age of urban development. Variability in streambank erosion and deposition were also observed by Palmer et al. (2014) for the agricultural Walnut Creek, lowa $\left(52.2 \mathrm{~km}^{2}\right)$, where streambanks showed lower erosion and deposition rates during periods of average precipitation and $80 \%$ of streambanks showed erosion when precipitation was $26 \%$ above normal (Palmer et al., 2014). For the agricultural and forested Cecina River, Italy, differences in streambank erosion for given storm events were related to variations in the initial streambank conditions and seasonal hydrograph characteristics (Luppi et al., 2009).

This study did not address the particular causes for variability in erosion and deposition rates for individual streambank changes. Factors affecting streambank erosion and deposition include 
the geotechnical properties of the banks, antecedent conditions of the streambanks, characteristics of flow, and freeze-thaw activity (Wolman, 1959; Hooke, 1979; Fitzpatrick et al., 1998; Simon et al., 2000; Rosgen, 2001 Julian and Torres, 2006; Wynn, 2006; Fox et al., 2007). An understanding of the causes of variability in streambanks from erosion to deposition required measurements of discharge and velocity, near streambank shear stress, temperature water content, and cohesion at each streambank, which were beyond the scope of this study.

Only after the largest event of the study period, TS Lee, were consistent results in geomorphic changes observed. Tropic al Storm Lee, a 100-year event that occurred in September 2011 was an erosive event that transported $56 \%$ of the sediment load for the entire study period. Measurements after TS Lee showed erosion for $82 \%$ of all streambanks, where $85 \%$ of streambanks that were eroding on the first resurvey continued to erode. Tropic al Storm Lee also had the effect of reversing streambanks from aggradation to erosion; $88 \%$ of streambanks that were aggrading before TS Lee switched to erosion (Fig. 6). When streambank changes were averaged by reach, the measurement after TS Lee had the highest rates of erosion (4.6 \pm $4.4 \mathrm{~cm} / \mathrm{y} ; 686 \pm 1014 \mathrm{~cm}^{2} / \mathrm{y}$; Fig. 7). A Mann-Whitney rank sum test confirms that streambank changes were significantly different before and after TS Lee (supplementary Tables 3A,B,D). Other measurement periods (first, third, and fourth) showed varying changes with roughly half of all streambanks showing erosion and deposition (Fig. 7).

Super Storm Sandy, a 5-year event that occurred on October 2012, showed the highest rate of change (erosion) for all bars $(13.5 \pm 35.0 \mathrm{~cm} / \mathrm{y})$ and for reach-averaged bar changes $(9.8 \pm 22.1$ $\mathrm{cm} / \mathrm{y}$; Fig. 9A,B). A Mann-Whitney test for the measurement after SS Sandy showed that changes in aggrading streambanks, gross reach bar changes, and cross-sectional changes in eroding bars were significant (supplementary Tables 3C,E, H). All surveys show the channel bed to be stable over the study period with minor changes after TS Lee and SS Sandy (Fig. 10).

We could not confirm that freeze-thaw activity explained all the observed differences in streambank changes between measurement periods. Large storms play an important role in channel change in UDR. Other studies have highlighted the importance of storms and large runoff events in controlling channel change in urban environments (Paul and Meyer, 2001; Chin, 2006). In the agricultural Cache Creek, California $\left(2696 \mathrm{~km}^{2}\right)$, streambanks eroded when mean daily flows $>85.0 \mathrm{~m}^{3} / \mathrm{s}$ or $0.032 \mathrm{~m}^{3} / \mathrm{s} / \mathrm{km}^{2}$ (Harmon, 1989). In Walnut Creek, lowa, streambank recession rates were significantly related to high stream flow with maximum daily discharge being a better predictor of sediment export from bank erosion than average daily discharge (Palmer et al., 2014).

The influence of flow affecting channel changes in the urban UDR is related to impervious area. An increase in impervious area in urban environments leads to hydrologic changes, increased magnitude and duration of peak flow, and increased volume of flow (Leopold, 1968). These hydrologic changes increase streampower leading to channel widening, streambank erosion, and channel incision (Wolman, 1967; Booth, 1990, 1991; Paul and Meyer, 2001). Flood peaks can increase flow by several orders of magnitude as a result of urbanization (Paul and Meyer, 2001). The effects of TS Lee on channel change in UDR is demonstrated by the measurements shown here, further emphasizing the role of large storms leading to channel erosion in urban environments.

\subsection{Statistical analysis of variables to understand streambank change and floodplain deposition}


Forward stepwise regression between the geomorphic variables and streambank change indicated that eroding streambanks as the response variable showed better statistical results than using all streambank changes (erosion and deposition; Table 6A). Drainage area was significant in explaining linear changes and cross-sectional area changes in eroding streambanks $(\mathrm{cm} / \mathrm{y})$. Channel top width was important in explaining cross-sectional area changes $\left(\mathrm{cm}^{2} / \mathrm{y}\right)($ Table $6 \mathrm{~A})$. Drainage area that is highly correlated to flow (supplementary Fig. 1 ) has been shown in other studies to be a significant variable explaining streambank change (Harmon, 1989; Martinez-Casanovas et al., 2004; Chen et al, 2005; Palmer et al., 2014). In Piedmont streams in Baltimore County, Maryland, bank erosion rates were correlated with drainage area (Donovan et al., 2015). Channel width has also been shown to be a significant variable in explaining streambank erosion for three basins of the Chesapeake Bay, which included the larger Difficult Run Watershed (Schenk et al., 2012).

The better statistical results for eroding banks versus all banks (eroding and depositing) may be related to the distinction between eroding and aggrading banks in the field. Banks aggrade by deposition of sediment on the toe of the bank. This sediment originates from either adjacent banks or from upstream sources. Sometimes the deposit on the toe of the bank was a bar (Fig. 13), while making the measurements it was often difficult to describe where the bank ends and a bar begins. Whereas eroding banks are easy to define, and because of the problem of distinguishing a bar from a bank, the statistical results for all banks (which include depositional banks that may in part be bar) are less significant.

Forward stepwise regression results examining geomorphic variables explaining floodplain deposition showed channel top width as significant (Table 6B). For the larger Difficult Run watershed, Hupp et al., 2013) identified channel gradient, sinuosity, and channel width/floodplain width as significant variables correlated to floodplain deposition. Channel top width is a significant variable explaining streambank erosion and floodplain deposition at the larger Difficult Run watershed $\left(151 \mathrm{~km}^{2}\right)$ scale and the smaller headwater Upper Difficult Run scale $\left(14.2 \mathrm{~km}^{2}\right)$.

\subsection{Differences by stream order}

Examination of net streambank changes (aggrading and eroding) by stream order using MannWhitney tests did not show significant differences between median values (supplementary Table 3D). When streambanks are separated into aggrading and eroding, significant differences occur in rates between lower order streambanks (first, second, and third) and higher order (fourth and fifth) streambanks (supplementary Tables 3C,D). Floodplain deposition rates also showed significant differences in deposition rates between lower order (first and second) and higher order(fourth and fifth) floodplains (supplementary Table 3J) . Higher order streambanks and floodplains showed higher median values of either erosion or deposition than lower order channels (supplementary Tables 3C,D,J). Drainage area is correlated to stream order (supplementary Fig. 2) and flow (supplementary Fig. 1). The greater rates of streambank erosion and floodplain deposition at higher stream orders in Upper Difficult Run may reflect the higher flow conditions occurring at these sites. In Linganore Creek, Maryland (another Piedmont stream in Maryland), floodplain deposition rates were correlated to drainage area where fourth and fifth order floodplains had the highest floodplain deposition rates (Gellis et al., 2015). 


\subsection{Sediment budget results}

The sediment budget underestimated the loads transported out of the Upper Difficult Run watershed by $2130 \mathrm{Mg} / \mathrm{y}$ or $61 \%$ of the measured suspended-sediment load (3010 Mg/y). The difference is most likely caused by contributions from upland sediment that were not measured in this study. This contribution of sediment is $36 \%$ of the total gross input of sediment, indicating that the upland sediment is still an important source of sediment in this urban environment where $23 \%$ of the land area was classified as impervious (Xian et al., 2011). Upland sediment sources include street residue, residential lawns, parks, forested areas and hillslopes, which other studies in urban areas have shown to be an important source of sediment (Allmendinger et al., 2007; Devereux et al., 2010; Smith and Wilcock, 2015). Devereux et al. (2010) and Allmendinger et al. (2007) included upland sources in their sediment budgets (street residue, residential lawns, parks, forested areas, and hillslopes). In the urban Anacostia Basin, Devereux et al. 2010) indicated that $30 \%$ of sediment was derived from upland slopes. In two suburban watersheds in Maryland, 50 to $67 \%$ of the sediment was derived from upland sources (Smith and Wilcock, 2015). In the urban San Diego Creek, California, upland sources were also determined as a residual from the sediment budget and showed a contribution of $33 \%$ to the total sediment budget (Trimble, 1997). Upland sources were not sampled as part of this study and are likely a factor in the difference between the sediment budget and the measured suspended-sediment load. Other reasons for the discrepancy in the measured and estimated sediment loads in UDR include errors associated with constructing a sediment budget (discussed below).

The sediment budget indicated that streambanks were an important source of sediment accounting for $42 \%$ of the total gross input of sediment. If storage terms are ignored, the mass of sediment supplied from streambanks is $70 \%$ of the suspended-sediment load. Similar to other urban watershed studies (Wolman, 1967; Booth, 1990, 1991; Paul and Meyer, 2001), the large percentage of impervious area in Difficult Run leads to increased streamflow and streambank erosion.

Although fourth order streambanks had 4.6 times the streambank erosion rate $\left(659 \mathrm{~cm}^{2} / \mathrm{y}\right)$ of first order channels $\left(144 \mathrm{~cm}^{2} / \mathrm{y}\right)$, first-order streambanks contributed the greatest percentage of streambank sediment (43\%; Table 7 ). First-order channels contain $56 \%$ of the total stream length compared to $5 \%$ of total stream length for fourth order channels, emphasizing the importance of lower-order stream measurements in estimating streambank contributions to a sediment budget. Gellis et al. (2012) reached a similar conclusion for a sediment budget constructed for two small watersheds in New Mexico, where low-order streams (first and second order) totaled over $80 \%$ of all channel lengths and contributed over $70 \%$ of the sediment.

The sediment budget showed that floodplains in UDR stored $75 \%$ of all storage quantified in the sediment budget. The mass of sediment deposited on floodplains was $52 \%$ of the suspendedsediment load, which is similar to the percentage (50\%) reported for Good Hope Tributary in the Maryland suburban area of Washington D.C. (Allmendinger et al., 2007). The floodplain deposition rates for UDR are similar to other rates of floodplain deposition at other sites in the 
Chesapeake Bay watershed (Gellis et al., 2009). First and fifth order floodplains stored the most floodplain sediment, $27 \%$ and $28 \%$, respectively, reflecting the greater width for fifth order channels and the greater length for first order channels (Table 2; supplementary Table 6). In Linganore Creek, Maryland, the highest rates of floodplain deposition were on fourth and fifth order streams (4.4 mm/y) (Gellis et al., 2015).

Hupp (2000) reported the importance of coastal plain floodplains in the Chesapeake Bay as storage sites for sediment and associated contaminants. Floodplain storage of sediment exceeds streambank erosion along the mainstem channel of the lower Difficult Run watershed (Hupp et al., 2013). Deposition rates shown here for UDR indicate that in this urban-suburban stream, headwater floodplains are also important areas of sediment storage. This has important management implications on preserving and restoring floodplains in headwater streams in urban areas. Channel beds and bars stored $17 \%$ and $8 \%$, respectively, of all stored sediment, indicating that in the overall sediment budget, in-channel storage of sediment is not as important a storage component as floodplains.

In constructing the sediment budget, we extrapolate all measurements by stream order to the entire watershed. Increasing stream order reflects increasing discharge (supplementary Fig. 2), which has been shown in this study to be important in describing streambank erosion and floodplain deposition (Fig. 12A; supplementary Tables 3C,D,J). Although we use stream orders to extrapolate channel measurements for the sediment budget, this approach does not necessitate that measurements among the different stream orders need to be statistically different, rather we used stream order to facilitate the extrapolation of measurements through the watershed (Gellis et al., 2015).

\subsection{Urban sediment yields in Chesapeake Bay}

Recent sediment yields shown here for UDR and nearby stream gages are some of the highest recorded in the Chesapeake Bay watershed (Fig. 3). Gellis et al. (2005) compiled sediment yields for Chesapeake Bay streams for the time periods 1952-1984 and 1985-2001 where the first and third highest sediment yields were tributaries to Difficult Run located downstream of UDR, Snakeden Branch at Reston, VA (399 Mg/km²/y; 1974-1978) and Smilax Branch at Reston, VA (346 Mg/km²/y; 1972-1975). These high sediment yields were thought to reflect suburban housing construction that was occurring in the Washington D.C. area in the 1970s (Yorke and Herb, 1978). Active construction was uncommon during the time period of the current study in UDR. Recent sediment yields for Fairfax County streams, South Fork Little Difficult Run, VA (376 Mg/km²/y), and UDR (295 Mg/km²/y) would rank as the second and fifth highest in the Gellis et al. (2005) summary, highlighting the importance of streambanks as a sediment source in urban areas.

Chin (2006) in a global review of geomorphic changes in urban rivers summarized four stages of sediment yield directly related to urbanization: (i) a pre-urban background rate, (ii) a construction phase resulting in dramatic increases in sediment, (iii) a developed stage with continued high sediment production from high peak flows and bank erosion, and (iv) an older 
urban landscape with decreasing sediment production as channels stabilize. Wolman (1967) depicted a similar model of sediment yields for the Washington DC metropolitan area from European colonization in the 1800s to urbanization in the 1970s (Fig. 14). Sediment yields were high during the agricultural land clearing period in the eighteenth and nineteenth centuries, rising again during the housing construction period in the 1960s. Wolman's (1967) curve predicted a decrease in sediment yield into the 1990s to pre-land-clearing rates (Fig. 14). The reduction in sediment yield was postulated to reflect the absence of surface soil as a sediment source as the watershed became impervious, a similar conclusion in Chin's (2006) model. Using the recent sediment yield data from stations in and around the Washington D.C. area (2005-2013; Fig. 2), combined with 1970s sediment yield data from streams in the Washington D.C. area (Gellis et al., 2005) and plotted on the Wolman curve, show that sediment yields although lower than the peak sediment yield do not decrease to low levels as depicted by Chin (2006) but remain high, similar to pre-urban agricultural sediment yields (Fig. 14). The high sediment yields reflect the importance of streambanks (this study; (Chin, 2006; Allmendinger et al., 2007; Devereux et al., 2010) and upland sediment (Allmendinger et al., 2007; Devereux et al., 2010; Smith and Wilcock, 2015) as sources of sediment in urban watersheds. Urbanization increases impervious land cover that can result in changes in hydrologic conditions, including increased volume of flow and stormwater energy (Chin, 2006). Greater flow and stream energy can lead to amplified channel incision and enlargement and, subsequently, an increase in streambank erosion (Hupp et al., 2013).

\subsection{Error analysis}

Construction of the sediment budget for UDR involved a number of field measurements that could contain errors and associated variability over spatial and temporal scales (Table 8). The discrepancy in the sediment budget with the measured sediment load includes all these errors (Table 8). The variability in field measurements is evident by the high standard deviation of many measurements that often are greater than the average for that measurement (e.g, third and fourth-order channels have standard deviations for channel bed change that is over 2 times the average bed measurement; supplementary Tables 2A, 4,5,6). The sediment budget underestimated the amount of sediment transported out of UDR by $61 \%$. The underestimate is most likely from not measuring upland erosion, as well as errors in the measurements of erosion and deposition (Table 8).

Errors in a sediment budget can be caused by differences in grain size between the geomorphic elements and suspended-sediment transport. Suspended sediment typically contains sediment that is $2.5 \mathrm{~mm}$ and finer (Spehar et al., 2007). The streambanks, channel beds, and bars of UDR contain a high percentage of sediment that is coarser than sand $(>0.063 \mathrm{~mm}$; supplementary Table 8) and may be transported as bedload. If the coarse fraction from source areas was omitted in the sediment budget, it is possible that a greater discrepancy may occur between the measured and estimated sediment output. An improvement on the sediment budget would be to measure or estimate bedload and construct a sediment budget by sedimentsize classes (Gellis et al., 2012).

\section{Conclusions}


Geomorphic measurements to understand and contrast rates of erosion and deposition are important in urban environments where sediment yields are high. This paper reports on changes in streambanks, channel beds and bars, and floodplains that were measured three to four times between 1 March 2010 and 18 January 2013, for the $14.2 \mathrm{~km}^{2}$, fifth order, urbansuburban Upper Difficult Run watershed in northern Virginia, USA. The measurements were used to construct a quasi-sediment budget; upland contributions were not measured and were estimated from the residual difference between the total sediment load and the budget measurements. Measurements were made before and after Tropical Storm Lee (8 September 2011), a 100-year event, and before and after SS Sandy (29-30 October 2012), a 5-year event. The occurrence of these storms presented an opportunity to see how large storms affect rates of streambank and floodplain change in an urban setting.

One of the main findings from this study is the temporal variability in streambank and bar, erosion, and deposition rates in this urban environment (except as a result of Tropical Storm Lee, a 100-year event when most reaches showed erosion). Only 15 and 5 of the 140 monitored streambanks continued to erode or aggrade, respectively, through all four measurement periods. Tropical Storm Lee was an erosive event where $82 \%$ of the streambanks eroded and where 88 streambanks that were aggrading before Tropical Storm Lee became erosional after the event. Statistical tests show that Tropical Storm Lee was a significant storm in changing the rates of channel erosion and deposition and emphasize how large storms affect geomorphic processes in urban settings. Channel-bed changes did not show any statistical differences between survey periods or between stream orders. We could not confirm that freeze-thaw activity explains all the observed differences in streambank changes between measurement periods. Variability in channel change is likely caused by factors affecting flow (impervious area) and geomorphic factors (channel width, depth, slope, and substrate).

Higher-order streams (fourth order) have the highest rates of streambank erosion, and fourth and fifth order have the highest rates of floodplain deposition. Linear streambank erosion rates $(\mathrm{cm} / \mathrm{y})$ are correlated to drainage area, and channel top width is correlated to cross-sectional streambank erosion $\left(\mathrm{cm}^{2} / \mathrm{y}\right)$ and floodplain deposition $(\mathrm{mm} / \mathrm{y})$. The higher rates of streambank erosion and floodplain deposition in Upper Difficult Run are related to higher flows in the higher order channels, a conclusion supported by other studies.

Statistical tests (forward stepwise regression and Mann-Whitney rank sum) used to understand streambank changes between measurement periods and among stream orders show eroding streambanks to have more significant statistical results compared to all streambank changes (combined erosion and deposition). Because of the difficulty in separating aggrading banks from bar deposition in the field, statistical results for eroding streambanks (which are clearly discernable in the field) are more significant.

The literature proposes a model that urban sediment yields decrease to background levels over time as a result of increasing impervious area and decreasing upland sediment supply. This model is not supported by urban watersheds in the Washington D.C. area, where most of the watersheds were urbanized by the 1980s, yet sediment yields recorded since 2008 are some of 
the highest in the Chesapeake Bay watershed. A quasi-sediment budget constructed for Upper Difficult Run from channel and floodplain changes underestimated the measured suspendedsediment load by $61 \%$.

Underestimation in the sediment budget includes measurement errors and most importantly, not incorporating upland sediment sources (forests, open space, roads) that other studies have highlighted as important sediment sources in urban-suburban watersheds. Assuming that the residuals in the sediment budget are from upland sources, this would indicate that $36 \%$ of the gross input of sediment is from these sources. Eroding streambanks accounted for $70 \%$ of the measured suspended-sediment load and $42 \%$ of the gross input of sediment. Similar to other urban watersheds, the large percentage of impervious area in Difficult Run leads to increased streamflow and streambank erosion. Floodplains stored $52 \%$ of the measured suspendedsediment load, highlighting the importance of floodplains in storing sediment in small headwater urban-suburban watersheds. An important question that comes out of this study is: in an urbansuburban environment, over what time period can streambanks continue to erode, remain an important source of sediment, and maintain high sediment yields?

\section{Acknowledgements}

We would like to thank U.S. Geological Survey reviewers John Jastram, Adam Benthem, and Marie Peppler as well as anonymous reviewers from the journal for helping to improve the manuscript. We also want to thank Richard Marston for his time performing substantial edits and suggestions. Funding for this study was provided by the U.S. Geological Survey Chesapeake Bay Program, with elements from related work funded by Fairfax County, Virginia.

\section{References}

Allmendinger NE, Pizzuto JE, Moglen GE, and Lewicki M. 2007. A sediment budget for an urbanizing watershed, 1951-1996, Montgomery County, Maryland, U.S.A. Journal of the American Watershed Association 43: 1483-1498.

Asselman NEM, and Middelkoop H. 1995. Floodplain sedimentation -- Quantities, patterns and processes. Earth Surface Processes and Landforms, 20(6): 481-499, DOI: 10.1002/esp.3290200602.

Austin SH, Krstolic JL, and Wiegand U. 2011. Peak-flow characteristics of Virginia streams: U.S. Geological Survey Scientific Investigations Report 2011-5144, 106 p.

Blake ES, Kimberlain TB, Berg RJ, Cangialosi JP, and Beven JL III, 2013. Hurricane Sandy, 22 - 29 October 2012: NOAA, National Weather Service, National Hurricane Center, Tropical Cyclone Reports, AL182012, 157 p. http://www.nhc.noaa.gov/data/tcr/AL182012 Sandy.pdf; Accessed online March 21, 2014.

Booth DB. 1990. Stream-channel incision following drainage-basin urbanization, Water Resources Bulletin 26: 407-417. DOI: 10.1111/j.1752-1688.1990.tb01380.x. 
Booth DB. 1991. Urbanization and the Natural Drainage System--Impacts, Solutions, and Prognoses, Northwest Environmental Journal 7: 93-118.

Booth, D.B., and Henshaw, P.C. 2001. Rates of channel erosion in small urban streams: chapter in M. Wigmosta and S. Burges, eds., Land Use and Watersheds: Human Influence on Hydrology and Geomorphology in Urban and Forest Areas: AGU Monograph Series, Water Science and Application Volume 2, pp. 17-38.

Brakebill JW, Ator SW, and Schwarz GE. 2010. Sources of Suspended-Sediment in the Chesapeake Bay Watershed: A Regional Application of the SPARROW Model, Journal of the American Water Resources Association 46: 757-776.

Brown DP. 2011. Tropical Cyclone Report Tropical Storm Lee, 2-5 September 2011: NOAA, National Weather Service, National Hurricane Center, Tropical Cyclone Reports, AL132011, 35 p. http://www.nhc.noaa.gov/data/tcr/AL132011 Lee.pdf, Last accessed online March 21, 2014.

Carter J, Owens PN, Walling DE, Leeks GJL. 2003. Fingerprinting suspended sediment sources in a large urban river system, Science of the Total Environment 314-316: 513-534.

Chen Y, Bhatia S, Buchanan J, DeKoskie D, and Vanschaack R. 2005. Effectiveness of Stream Restoration in Reducing Stream Bank Erosion: The Case of Batavia Kill Stream Restoration Projects, New York. Managing Watersheds for Human and Natural Impacts: Moglen, GE, ed., American Society of Civil Engineers, Proceedings, Watershed Management Conference 2005, Williamsburg, Virginia, United States, July 19-22, 2005. p. 1-12. DOI: 10.1061/40763(178)122.

Chin, A. 2006. Urban transformation of river landscapes in a global context. Geomorphology 79: 460-487.

de Vente, J, Poesen, J, Arabkhedri, M, and Verstraeten, G. 2007. The sediment delivery problem revisited. Progress in Physical Geography 31(2): 155-178, doi:10.1177/0309133307076485.

Devereux OH, Prestegaard KL, Needelman BA, Gellis AC. 2010. Suspended-sediment sources in an urban watershed, Northeast Branch Anacostia River, Maryland, Hydrological Processes 24: 1391-1403. DOI: 10.1002/hyp.7604

Doheny EJ, Starsoneck RJ, Mayer PM, and Striz EA. 2007. Pre-restoration geomorphic characteristics of Minebank Run, Baltimore County, Maryland, 2002-04, U.S. Geological Survey Scientific Investigations Report 2007-5127, 49 p.

Donovan, M, Miller, A, Baker, M, and Gellis, A.. 2015. Sediment contributions from floodplains and legacy sediments to Piedmont streams of Baltimore County, Maryland: Geomorphology, 235: 88-105.

Fitzpatrick FA, Waite IR, D'Arconte PJ, Meador MR, Maupin MA, and Gurtz ME.1998. Revised methods for characterizing stream habitat in the National Water-Quality Assessment Program: U. S. Geological Survey Water-Resources Investigations Report 98-4052, 67 p. 
Fox GA, Chu-Agor ML, and Wilson GV. 2007. Seepage erosion: A significant mechanism of stream bank failure: Proceedings of the American Society of Civil Engineers (ASCE) World Environmental and Water Resources Congress, May 15-19, 2007, Tampa, FL, 14 p. (CD-ROM)

Gellis, A.C., and Brakebill, J.W., 2013. Sediment Sources and Transport in the Chesapeake Bay Watershed: U.S Geological Survey Chesapeake Bay Activities, available at http://chesapeake.usgs.gov/sciencesummary-sedimentsourcesandtransport.html. Last accessed online March 29, 2014.

Gellis A, Smith S, and Stewart S. 2003. Watershed Sediment Sources: in, Langland M, and Cronin T. eds., A summary report of sediment processes in Chesapeake Bay and watershed, U.S. Geological Survey Water-Resources Investigations Report 2003-4123, p. 29-33.

Gellis AC, Banks WSL, Langland MJ, and Martucci SK. 2005. Summary of suspended-sediment data for streams draining the Chesapeake Bay watershed, water years 1952-2002, U.S. Geological Survey Scientific Investigations Report 2004 5056, 59 p.

Gellis AC, Hupp CR, Pavich MJ, Landwehr JM, Banks WSL, Hubbard BE, Langland MJ, Ritchie, JC, and Reuter JM. 2009. Sources, transport, and storage of sediment at selected sites in the Chesapeake Bay Watershed, U.S. Geological Survey Scientific Investigations Report 20085186, $95 \mathrm{p}$.

Gellis AC, Pavich MJ, Ellwein AL, Aby S, Clark I, Wieczorek ME, and Viger R. 2012. Erosion, storage, and transport of sediment in two subbasins of the Rio Puerco, New Mexico: Geological Society of America Bulletin 124: 817-841.

Gellis AC, Noe GB, Clune JW, Myers MK, Hupp CR, Schenk ER, and Schwarz GE. 2015. Sources of fine grained sediment in the Linganore Creek watershed, Frederick and Carroll Counties, Maryland, 2008-10: U.S. Geological Survey Scientific Investigations Report 20145147, 56 p., http://dx.doi.org/10.3133/sir20145147.

Harden CP, Chartrand K, and Henry E. 2010. Temporal variability of bank erosion in East Tennessee headwater streams. Southeastern Geographer 50: 484-502.

Harmon, J. 1989. Streamflow, Sediment Discharge, and Streambank Erosion in Cache Creek, Yolo County, California, 1953-86. U.S. Geological Survey, Water-Resources Investigations Report 88-4188. Sacramento, CA. 40 p.

Helsel, D.R., and Hirsch, R.M., 1992. Statistical Methods in Water Resources. Elsevier Science B.V.: Amsterdam; $529 p$

Homer CG, Dewitz JA, Yang L, Jin S, Danielson P, Xian G, Coulston J, Herold ND, Wickham JD, and Megown K. 2015. Completion of the 2011 National Land Cover Database for the conterminous United States-representing a decade of land cover change information: Photogrammetric Engineering and Remote Sensing 81: 345-354.

Hooke JM. 1979. An analysis of the processes of river bank erosion: Journal of Hydrology 42: 39-62, http://dx.doi.org/10.1016/0022-1694(79)90005-2. 
Hooke JM, and Yorke L. 2011. Channel bar dynamics on multi-decadal timescales in an active meandering river: Earth Surface Processes and Landforms 36: 1910-1928.

Hupp CR. 2000. Hydrology, geomorphology, and vegetation of Coastal Plain rivers in the southeastern United States: Hydrological Processes 14: 2991-3010.

Hupp CR, and Bazemore DE. 1993. Spatial and temporal aspects of sediment deposition in West Tennessee forested wetlands: Journal of Hydrology 141: 179-196.

Hupp CR, Noe GB, Schenk ER, and Benthem A. 2013. Recent and historic sediment dynamics along Difficult Run, a suburban Virginia Piedmont stream: Geomorphology 180-181: 156-169.

Jacobson RB, and Coleman DJ. 1986. Stratigraphy and recent evolution of Maryland Piedmont flood plains, American Journal of Science 286: 617-637.

Jastram JD. 2014. Streamflow, water quality, and aquatic macroinvertebrates of selected streams in Fairfax County, Virginia, 2007-12, U.S. Geological Survey Scientific Investigations Report 2014-5073, 68 p., http://dx.doi.org/10.3133/sir20145073

Jin S, Yang L, Danielson P, Homer C, Fry J, and Xian G. 2013. A comprehensive change detection method for updating the National Land Cover Database to circa 2011. Remote Sensing of Environment 132: 159-175.

Julian JP, and Torres R. 2006. Hydraulic erosion of cohesive riverbanks, Geomorphology 76:193-206, http://dx.doi.org/10.1016/j.geomorph.2005.11.003

Kelsey, H. M. 1980. A sediment budget and an analysis of geomorphic process in the Van Duzen River basin, northcoastal California, 1941-1975, Bulletin of the Geological Society of America, Part 1, v. 91, p. 190-195.

Khaja F, Cahill AP, Maliszewski P, and Steffek T. 2014. Demographic Report 2014, prepared by Economic, Demographic and Statistical Research, Countywide Service Integration and Planning Management (CSIPM), Department of Neighborhood and Community Services, Fairfax County, Virginia, available online at http://www.fairfaxcounty.gov/demogrph/demrpts/report/fullrpt.pdf

Kiely M, Cahill AP, and Shangraw S. 2006. Anticipating the future-A discussion of trends in Fairfax County: Fairfax County Department of Systems Management for Human Services, available online at http://www.fairfaxcounty.gov/demogrph/archives/archive general/anticipating future.pdf

Lambert CP and Walling DE. 1987, Floodplain sedimentation: a preliminary investigation of contemporary deposition within the lower reaches of the River Culm, Devon, UK. Geografiska Annaler 69A: 393-404.

Langland MJ, Cronin T, and Phillips S. 2003. Executive Summary: in, Langland MJ, and Cronin $\mathrm{T}$, eds., A summary report of sediment processes in Chesapeake Bay and watershed, U.S. Geological Survey Water-Resources Investigations Report 2003-4123, p. 1-18.

Leopold LB. 1968. Hydrology for Urban Land Planning - A Guidebook on the Hydrologic Effects of Urban Land Use, U.S. Geological Survey Circular 55, 18 p.

Leopold, L. B., Emmett, W.W., and Myrick, R.M, 1966. Channel and hillslope processes in a semi-arid area, New Mexico, U.S. Geological Survey Professional Paper 352-G, 249 p. 
Lorenz DL, and others, 2011, USGS library for S-PLUS for Windows -- Release 4.0: U.S. Geological Survey Open-File Report 2011-1130.

Luppi L, Rinaldi M, Teruggi LB, Darby SE, Nardi L. 2009. Monitoring and numerical modelling of riverbank erosion processes: a case study along the Cecina River (Central Italy). Earth Surface Processes and Landforms 34: 530-546. DOI: 10.1002/esp.1754

Macfall J, Robinette P, and Welch D. 2014. Factors Influencing Bank Geomorphology and Erosion of the Haw River, a High Order River in North Carolina, since European Settlement. PLoS ONE 9(10), DOI:10.1371/journal.pone.0110170.

Magilligan FJ. 1985. Historical floodplain sedimentation in the Galena River basin, Wisconsin and Illinois. Annals of the Association of 'American Geographers 75: 583-594.

Maliszewski P, 2014. Housing and Population through the Decades in Fairfax County: Demographic, Economic and Statistical Research, Department of Neighborhood and Community Services, Fairfax County, Virginia, http://www.fairfaxcounty.gov/demogrph/datavis/datavis pdf/housing population datavis.pdf, accessed November 21, 2015

Martinez-Casanovas JA, Ramos MC, and Poesen J. 2004. Assessment in sidewall erosion in large gullies using multi-temporal DEMs and logistic regression analysis, Geomorphology 58: 305-321.

Merritts D, Walter R, Rahnis M, Hartranft J, Cox S, Gellis A, Potter N, Hilgartner W, Langland M, Manion L, Lippincott C, Siddiqui S, Rehman Z, Scheid C, Kratz L, Shilling A, Jenschke M, Datin K, Cranmer E, Reed A, Matuszewski D, Voli M, Ohlson E, Neugebauer A, Ahamed A, Neal C, Winter A, and Becker S. 2011. Anthropocene streams and base-level controls from historic dams in the unglaciated Mid-Atlantic Region, USA: Philosophical Transactions of the Royal Society A-Mathematical, Physical and Engineering Sciences 369: 976-1009.

Middelkoop H, Van Der Perk M. 1998. Modeling Spatial Patterns of Overbank Sedimentation on Embanked Floodplains. Geografiska Annaler: Series A, Physical Geography 80:95-109. doi:10.1111/j.0435-3676.1998.00029.x

Miller CV, Chanat JG, and Bell JM. 2013. Water quality in the Anacostia River, Maryland and Rock Creek, Washington, D.C.: Continuous and discrete monitoring with simulations to estimate concentrations and yields of nutrients, suspended sediment, and bacteria, U.S. Geological Survey Open-File Report 2013-1034, 37 p.

National Oceanic and Atmospheric Administration (NOAA), 2014. National Climatic Data Center (NCDC): Accessed January 2014 at http://www.ncdc.noaa.gov/.

Nelson EJ, and Booth DB. 2002. Sediment sources in an urbanizing, mixed land-use watershed, Journal of Hydrology 264: 51-68. 
Noe GB, and Hupp CR. 2009. Retention of riverine sediment and nutrient loads by Coastal Plain floodplains, Ecosystems 12: 728-746.

Palmer JA, Schilling KE, Isenhart TM, Schultz RC, Tomer MD. 2014. Streambank erosion rates and loads within a single watershed: Bridging the gap between temporal and spatial scales, Geomorphology 209: 66-78.

Paul MJ, and Meyer JL. 2001. Streams in the urban landscape. Annual Review of Ecology and Systematics 32: 333-365.

Pizzuto J, and O'Neal M. 2010. Increased mid-20th century river bank erosion rates related to the demise of mill dams, South River, Virginia. Journal of Geology 37:19-22. DOI: 10.1130/G25207A.1

Poleto C, Merten GH, and Minella JP. 2009. The identification of sediment sources in a small urban watershed in southern Brazil: An application of sediment fingerprinting, Environmental Technology 30(11): 1145-1153.

Rosgen DL. 1994. A classification of natural rivers, Catena 22:169-199.

Rosgen DL. 2001. A practical method of computing streambank erosion rate.

Proceedings of the Seventh Federal Interagency Sedimentation Conference 2: 9-15, March 2529, 2001, Reno, NV. Available on the Wildland Hydrology website:

http://www.wildlandhydrology.com/assets/Streambank_erosion_paper.pdf, last accessed Feb 21, 2016.

SAS Institute. 2008. SAS System, release 9.4, SAS Institute Inc., Carey, NC, USA.

Schenk ER, Hupp CR, Gellis AC, and Noe G. 2012. Developing a new stream metric for comparing stream function using a bank-floodplain sediment budget: a case study of three Piedmont streams. Earth Surfaces Processes and Landforms 38: 771-784.

Simm DJ. and Walling DE. 1998. Lateral variability of overbank sedimentation on a Devon flood plain: Hydrological Sciences 43(50: 715-732, DOI:10.1080/02626669809492168.

Simon A, Curinni A, Darby SE, and Langendoen EJ. 2000. Bank and near-bank processes in an incised channel: Geomorphology 35:193-217, http://dx.doi.org/10.1016/S0169-555X(00)00036$\underline{2}$.

Smith SMC, and Wilcock PR. 2015. Upland sediment supply and its relation to watershed sediment delivery: Geomorphology 232: 33-46.

Spehar RL, Cormier SM, and Taylor DL. 2007. Candidate Causes-- Sediments. In, causal analysis, diagnosis decision information system, USEPA Website. U.S. Environmental Protection Agency, Washington, DC, EPA/600/R-08/022.

Trimble SW. 1997. Contribution of stream channel erosion to sediment yield from an urbanizing watershed. Science 278: 1442-1444. 
US Department of Commerce, 2011. Heavy Rainfall from the Remnants of Tropical Storm Lee: National Oceanic and Atmospheric Administration, National Weather Service, News Headlines, available at http://www.weather.gov/lwx/events_20110905_lee.

USEPA (U.S. Environmental Protection Agency), 2010. Chesapeake Bay Phase 5.3 Community Watershed Model. EPA 903510002 - CBP/TRS-303-10. U.S. Environmental Protection Agency, Chesapeake Bay Program Office, Annapolis MD, December 2010.

Walter R, and Merritts R. 2008. Natural streams and the legacy of water-powered milling: Science 319: 299-304.

Weil M. 2011. D.C. area's recent rainfall might be once-in-a-thousand-years event: Washington Post, Post Local, published September 16, 2011, 1 p. Accessed March 21, 2014 at http://www.washingtonpost.com/local/dc-areas-recent-rainfall-might-be-once-in-a-thousandyears-event/2011/09/16/gIQAtU1qYK story.html

Whitlow JR, and Gregory KJ. 1989. Changes in urban stream channels in Zimbabwe. Regulated Rivers 4: 27-42.

Wolman MG. 1959. Factors influencing erosion of a cohesive river bank: American Journal of Science 257: 204-216.

Wolman MG. 1967. A cycle of sedimentation and erosion in urban river channels: Geografiska Annaler. Series A, Physical Geography 49: 385-395.

Wynn T. 2006. Streambank retreat --A primer: watershed update, January-March 2006, American Water Resources Association Hydrology and Watershed Management Technical Committee 4:1-14.

Xian G, Homer C, Dewitz J, Fry J, Hossain N and Wickham J. 2011. The change of impervious surface area between 2001 and 2006 in the conterminous United States. Photogrammetric Engineering and Remote Sensing 77(8):758-762.

Yorke TH, and Herb WJ. 1978. Effects of urbanization on streamflow and sediment transport in the Rock Creek and Anacostia River basins, Montgomery County, Maryland, 1962-74: U.S. Geological Survey Water-Supply Paper 1003, 76 p.

FIGURE CAPTIONS

Fig. 1. Location of sites in Upper Difficult Run $\left(14.2 \mathrm{~km}^{2}\right)$ watershed used to monitor changes in streambanks, channels beds and bars, and floodplains. Also shown is the larger Difficult Run watershed $\left(151 \mathrm{~km}^{2}\right.$ ), Chesapeake Bay boundary, and Piedmont Physiographic boundary. Map source: National Land Cover Database 2011 (Homer et al., 2015; Jin et al., 2011).

Fig. 2. Sediment yields for urban watersheds in the Washington D.C. area. 1. Paint Branch near College Park, MD; 2. NE Anacostia River at Riverdale, MD; 3. Northwest Branch Anacostia River near Hyattsville, MD ; 4. Rock Creek at Joyce Road, Washington, D.C.; 5. Difficult Run above Fox Lake near Fairfax, VA; 6. South Fork Little Difficult Run, VA; 7. Flatlick Branch above 
Frog Branch at Chantilly, VA; 8. Dead Run at Whann Avenue near McLean, VA; 9. Average for Piedmont Physiographic Province.

Fig. 3. Land use percentages in 2011 (Homer, 2015) and impervious cover (Xian et al., 2011) by drainage area for Upper Difficult Run, VA, USA.

Fig. 4. Summary of mean daily discharge (Difficult Run above Fox Lake, VA) and periods of measurements used to describe bank, channel bed and bar, and floodplain changes. Spaces between the measurements indicate that no measurements were made.

Fig. 5. All 140 streambank changes for the period of study by stream order showing: $(A)$ linear rates of change $(\mathrm{cm} / \mathrm{y}),(B)$ cross-sectional area change $\left(\mathrm{cm}^{2} / \mathrm{y}\right)$. (C) Right streambank at site R31 where annual rate of streambank erosion was $23.6 \mathrm{~cm} / \mathrm{y}(5400 \mathrm{~cm} / \mathrm{y})$. Bank height is 2.29 $\mathrm{m}$. [Positive values indicate erosion, negative values indicate deposition.]

Fig. 6. Summary of individual streambank changes (A) before and after TS Lee, (B) after TS Lee and before SS Sandy, and (C) after SS Sandy. Changes are summarized by eroding and aggrading banks from the previous survey to whether they remained eroding and aggrading or switched in the current survey.

Fig. 7. Changes in reach-averaged streambanks changes for the 4 survey periods defined before and after TS Lee and SS Sandy showing (A) linear rates of change and (B) crosssectional rates of change. [Positive values equal erosion, negative values equal deposition][ see Fig. 5 for explanation of box plots.]

Fig. 8. (A) Number of freeze-thaw days between streambank pin surveys normalized by the number of days between surveys. Normalized freeze-thaw days plotted against (B) streambank changes in $\mathrm{cm} / \mathrm{y}$ and $(C)$ streambank changes in $\mathrm{cm}^{2} / \mathrm{y}$. Statistical relations in $(B)$ and $(C)$ were not significant. Temperature data was obtained for Vienna, VA located $\sim 5.8 \mathrm{~km}$ east of the Difficult Run at Fox Lake station (NOAA, 2014).

Fig. 9. Linear changes in bars $(\mathrm{cm} / \mathrm{y})$ for the four survey periods and for the period of study are shown for $(A)$ all bars and $(B)$ reach-averaged changes. [Positive values equal erosion, negative values equal deposition: see Fig. 5 for explanation of box plots.]

Fig. 10. Changes in channel bed (A) for resurvey periods after TS Lee and SS Sandy and for the period of study. (B) Changes in the channel bed shown by stream order for the period of study. [Positive values equal erosion, negative values equal deposition: see Fig. 5 for explanation of box plots.]

Fig. 11. Floodplain deposition shown for( A) all 35 floodplain cross sections for resurvey periods (before TS Lee, after TS Lee, after SS Sandy, and for the study period; (B) the amount of floodplain deposition by cross section for the resurvey periods by bin; and (C) changes in the reach-averaged floodplain deposition rates by stream order for the period of study.

Fig. 12. Results of forward stepwise regression showing significant variables explaining eroding streambank change and floodplain deposition. (A) Drainage area against linear rates of eroding 
streambank and (B) channel top width vs. cross-sectional rates of eroding streambanks; (C) channel top width vs. floodplain deposition. [ ${ }^{*}$ slope of regression is significant $(p<0.05)$ and residuals are normally distributed.]

Fig. 13. Example of a bar and bank along the same transect (ID R35; Fig. 1), photo 1 March 1 2010, view looking upstream). Bar outline is shown in yellow. Bank height is $\sim 1$.

Fig. 14. Sediment yield curve for the Washington D.C. metropolitan area (Wolman, 1967) plotted with more recent sediment yield data (1963-1978 and 2005-2012) from urban-suburban areas near Washington D.C. in Maryland and Virginia. 


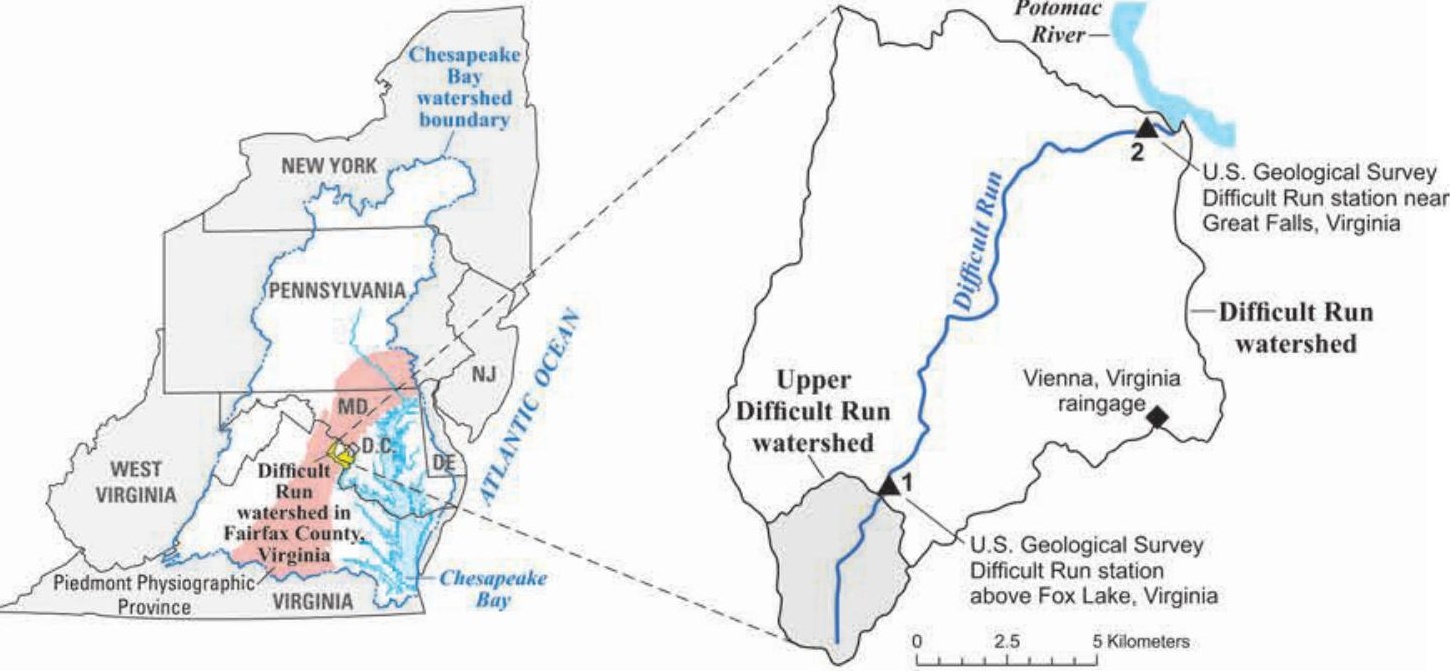

$77^{\circ} 22^{\prime} 0^{\circ}$

$77^{\circ} 21^{\prime} 30^{\prime \prime}$

$77^{\circ} 21^{\circ} 0^{\prime \prime}$

$77^{\circ} 20^{\prime} 30^{\prime \prime}$

$77^{\circ} 20^{\prime} 0^{\prime \prime}$

$77^{\circ} 19^{\prime} 30^{\prime \prime}$

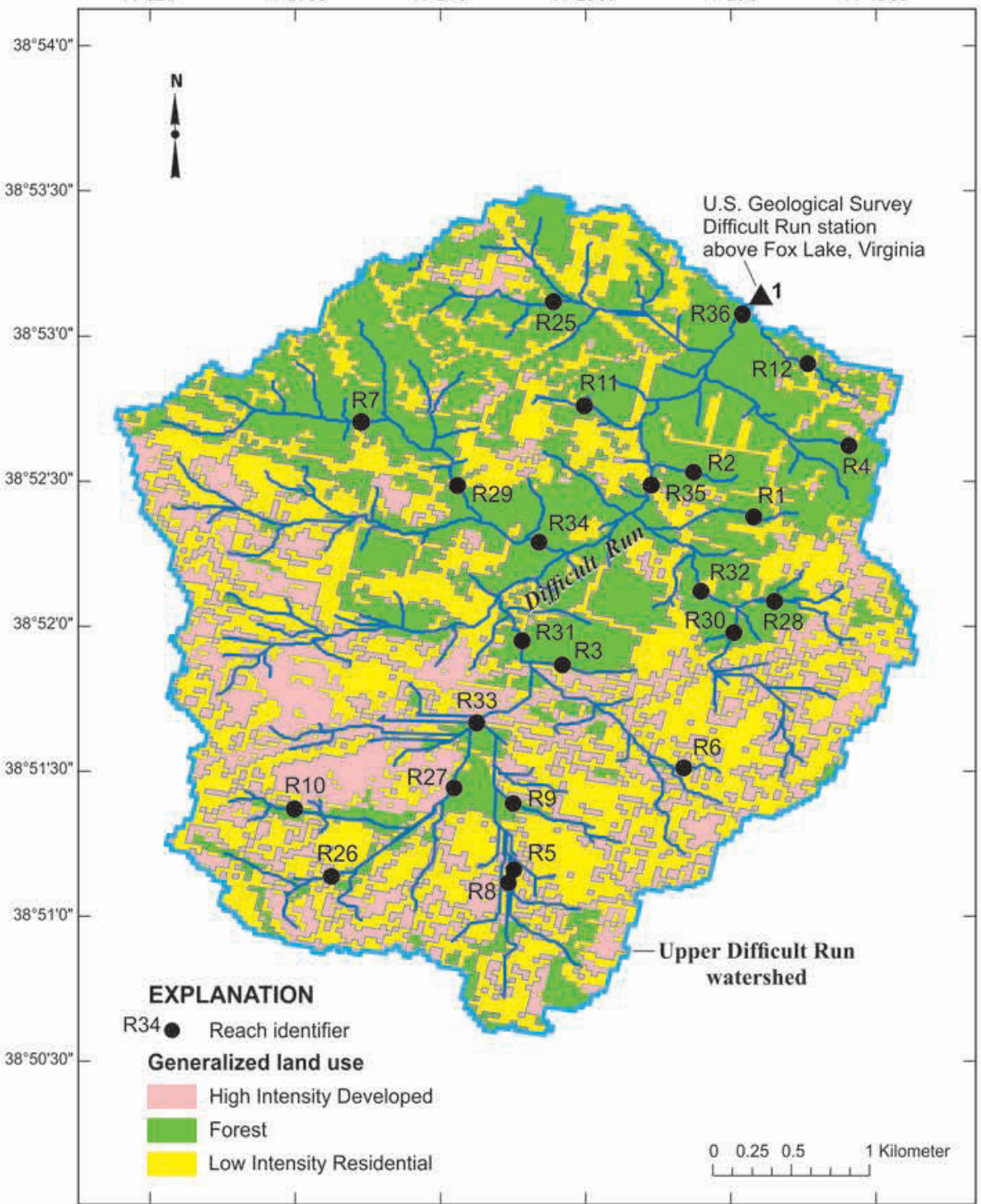




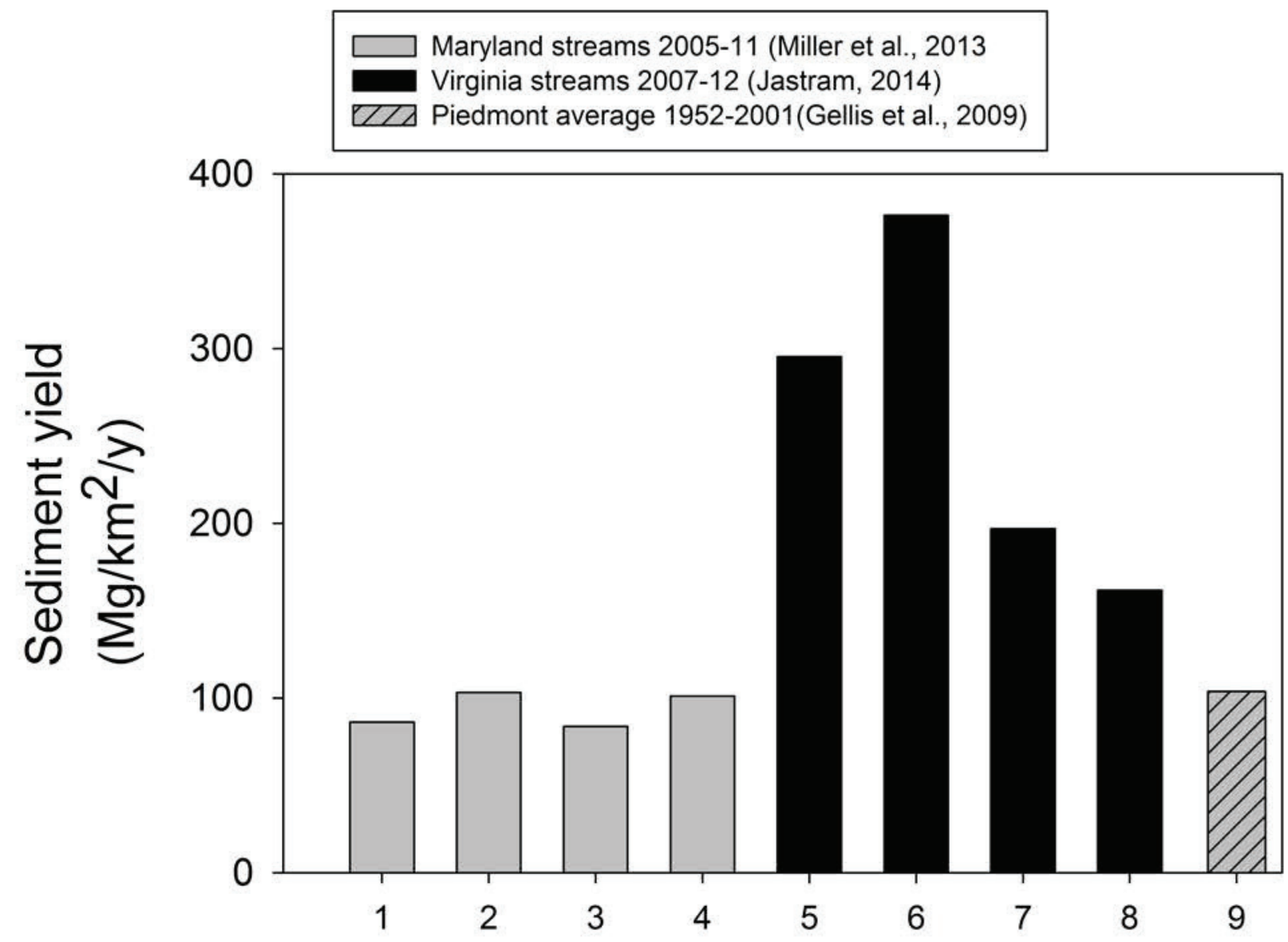




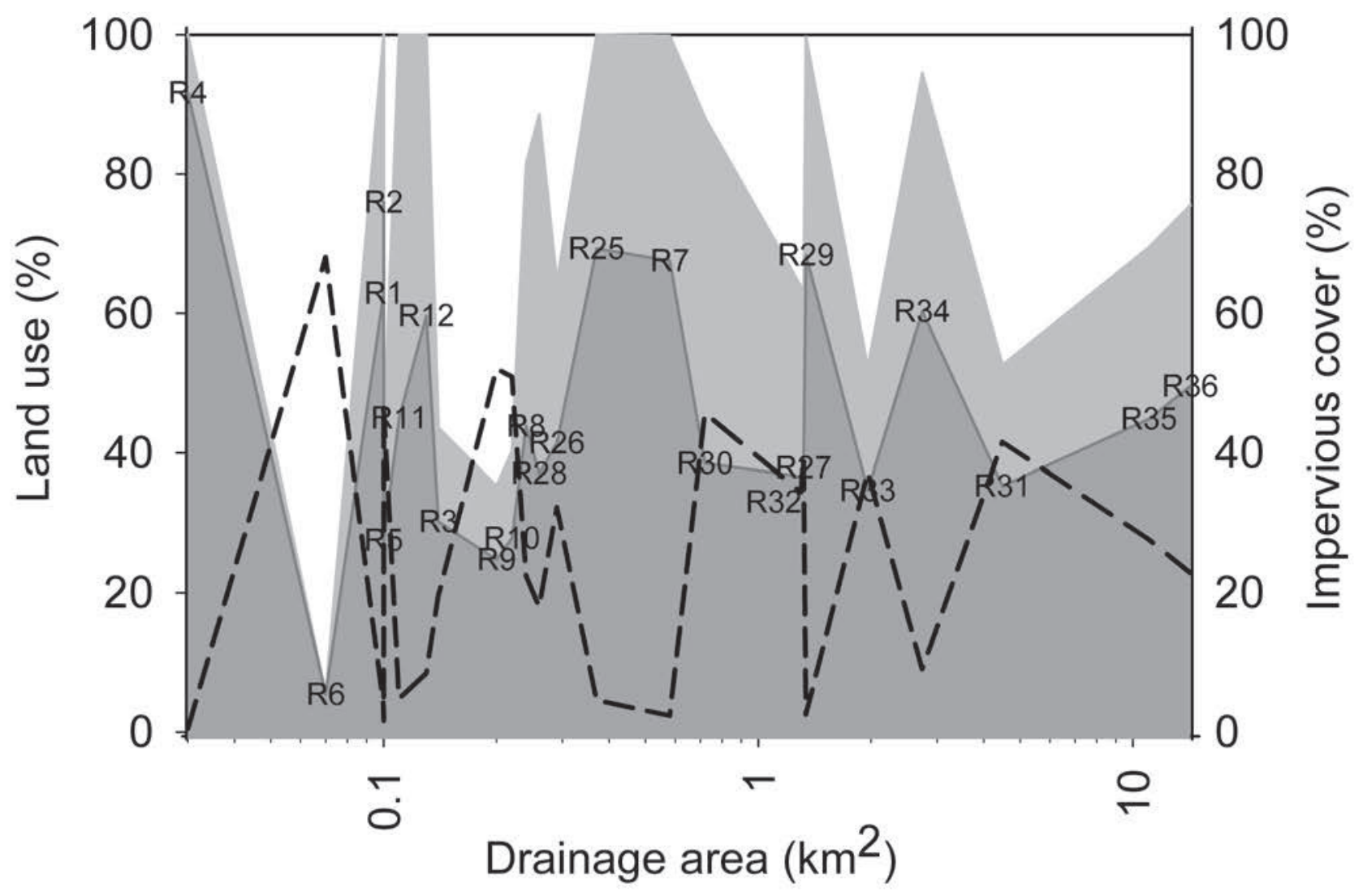

High Intensity Developed Low Intensity Residential Forest

- - Impervious cover (\%) 


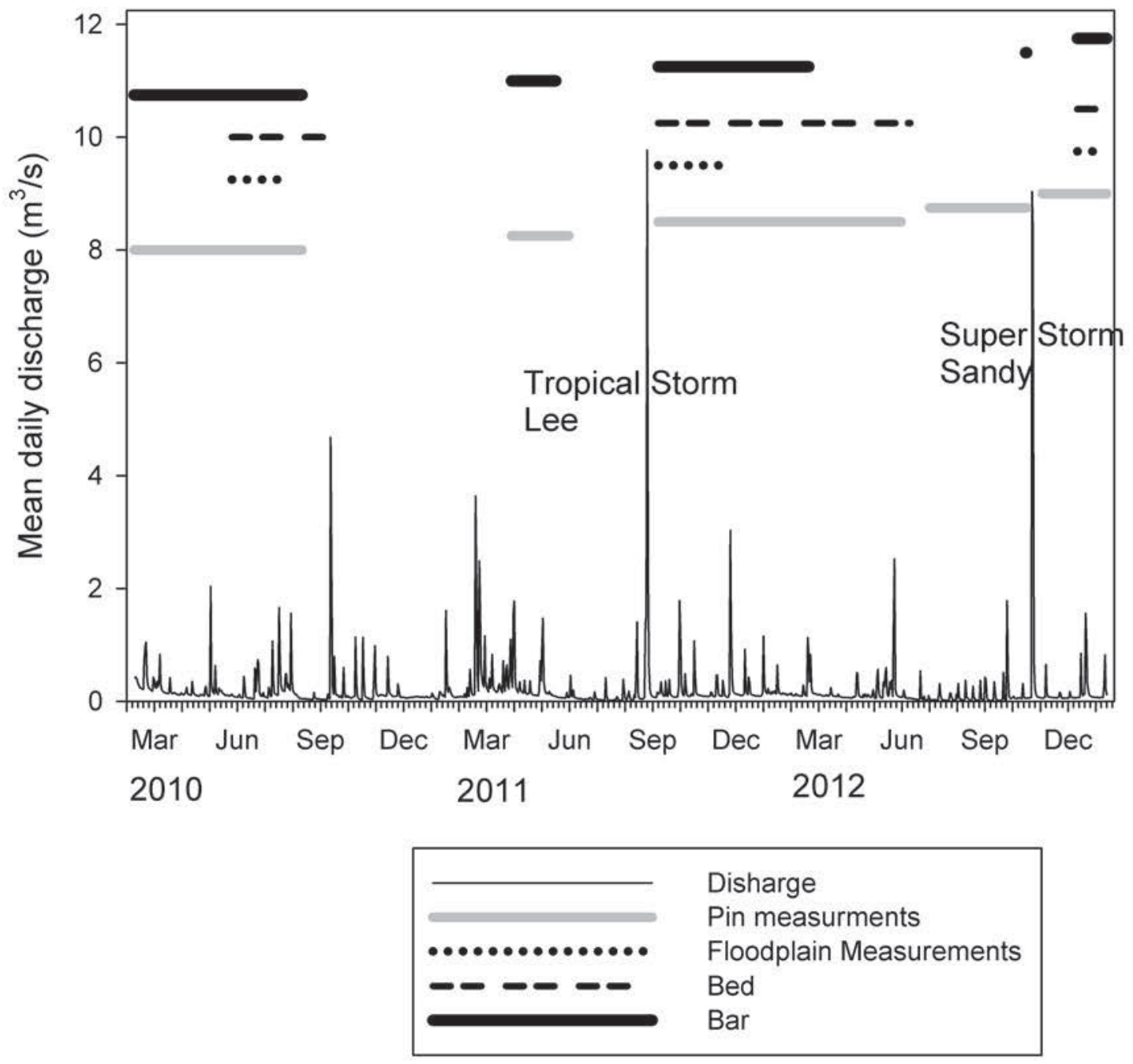



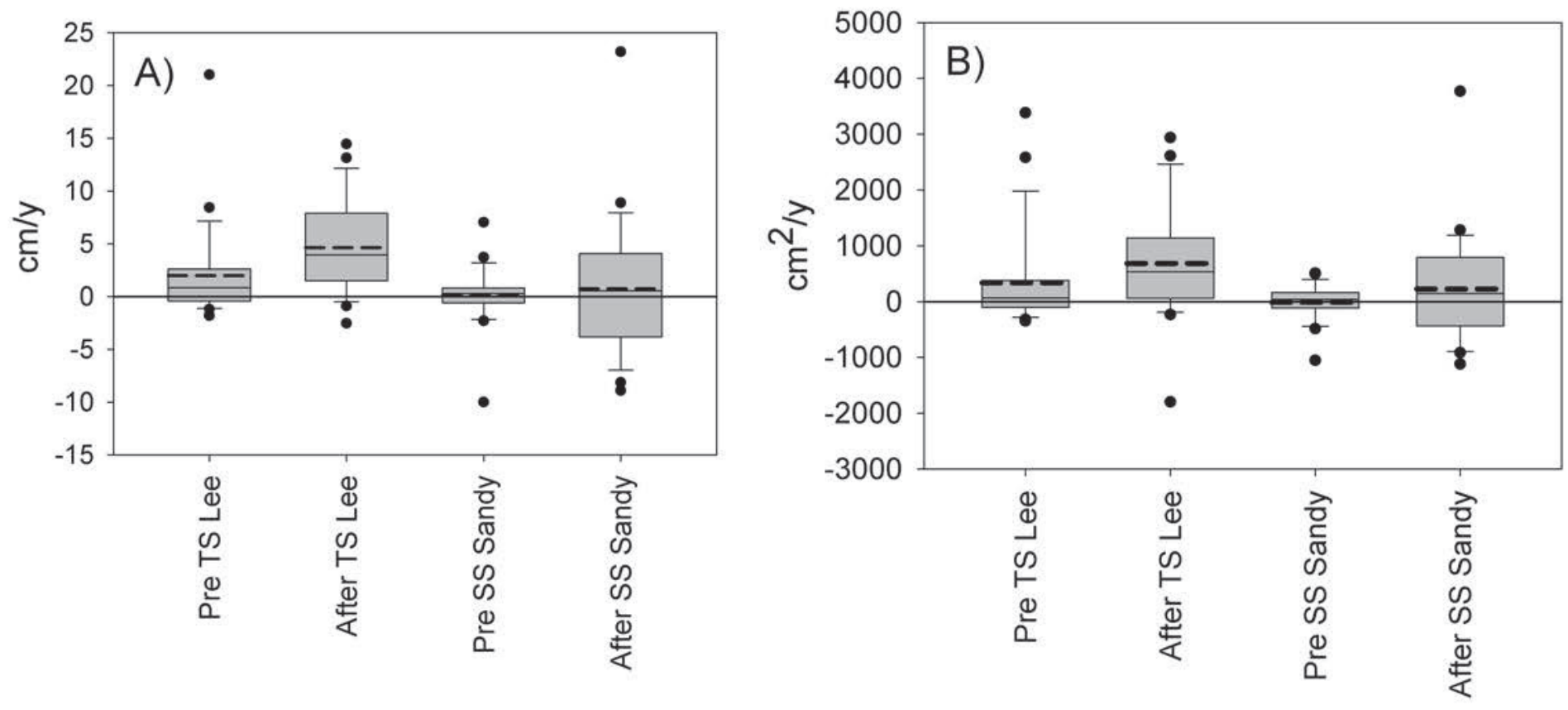

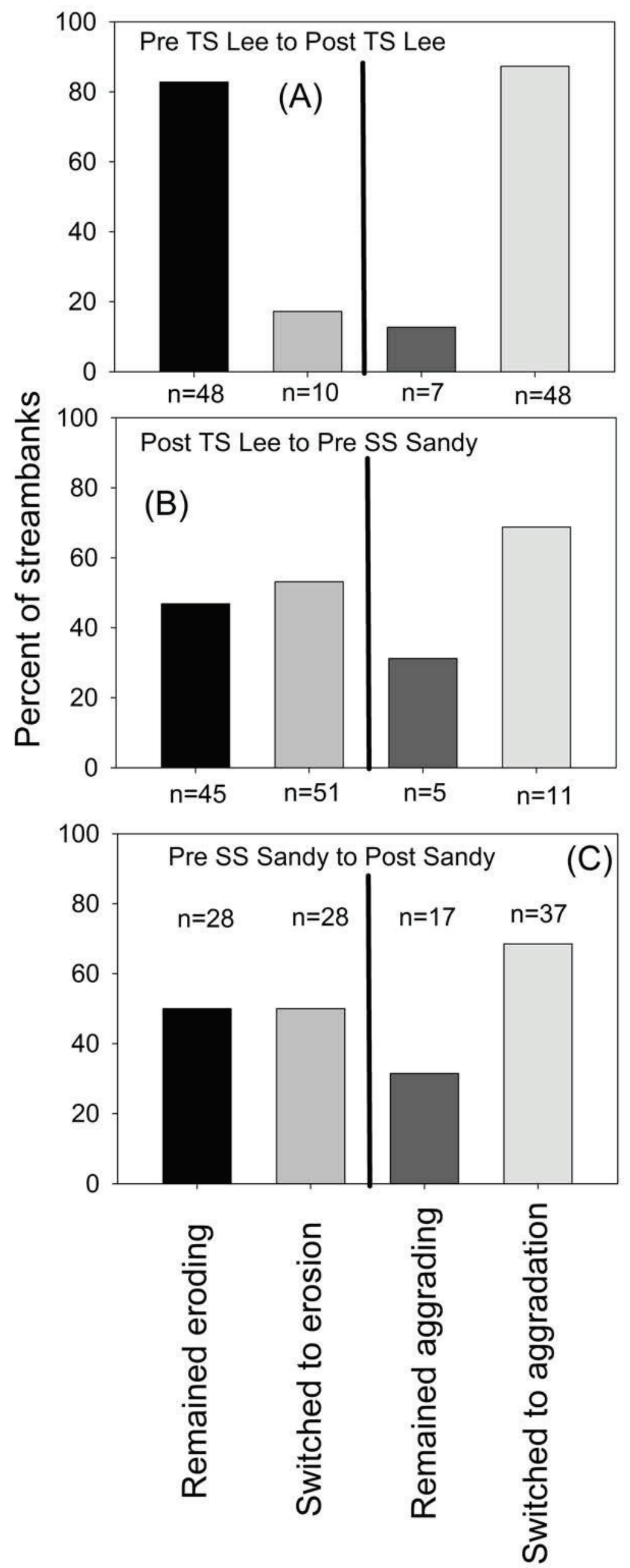


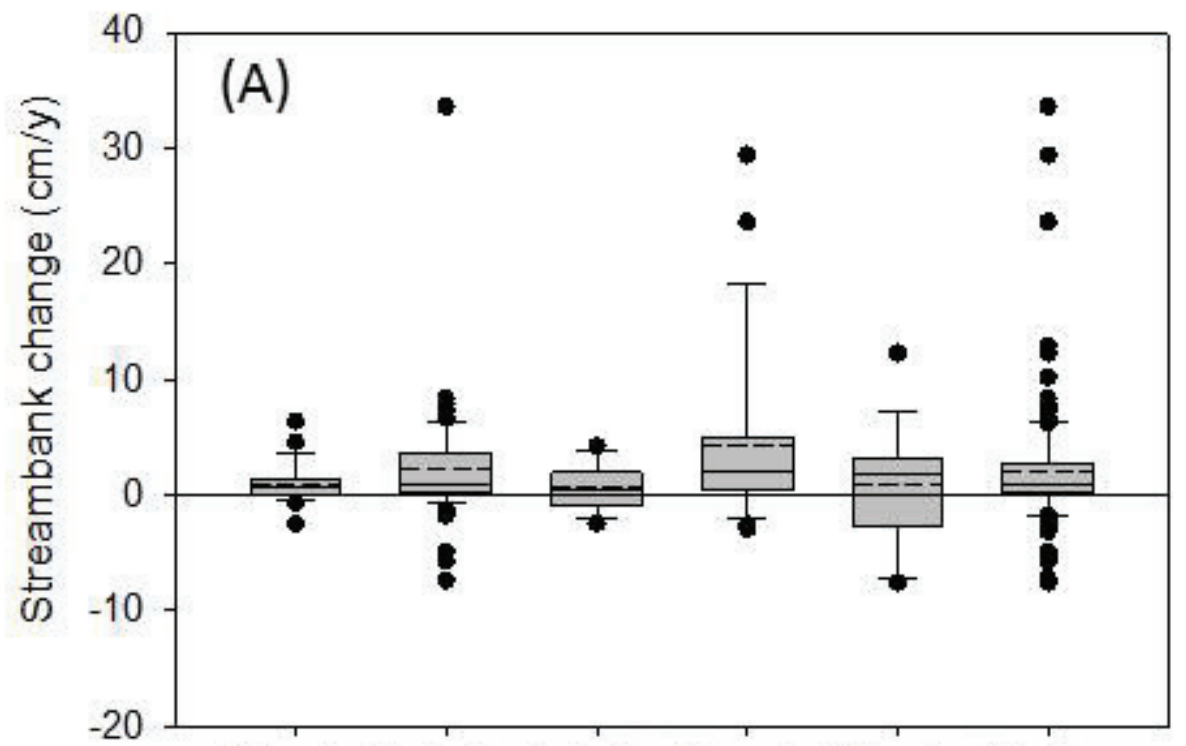

1st order 2 nd order 3 rd order 4 th order 5 th order All orders $n=29 \quad n=56 \quad n=14 \quad n=24 \quad n=17 \quad n=140$

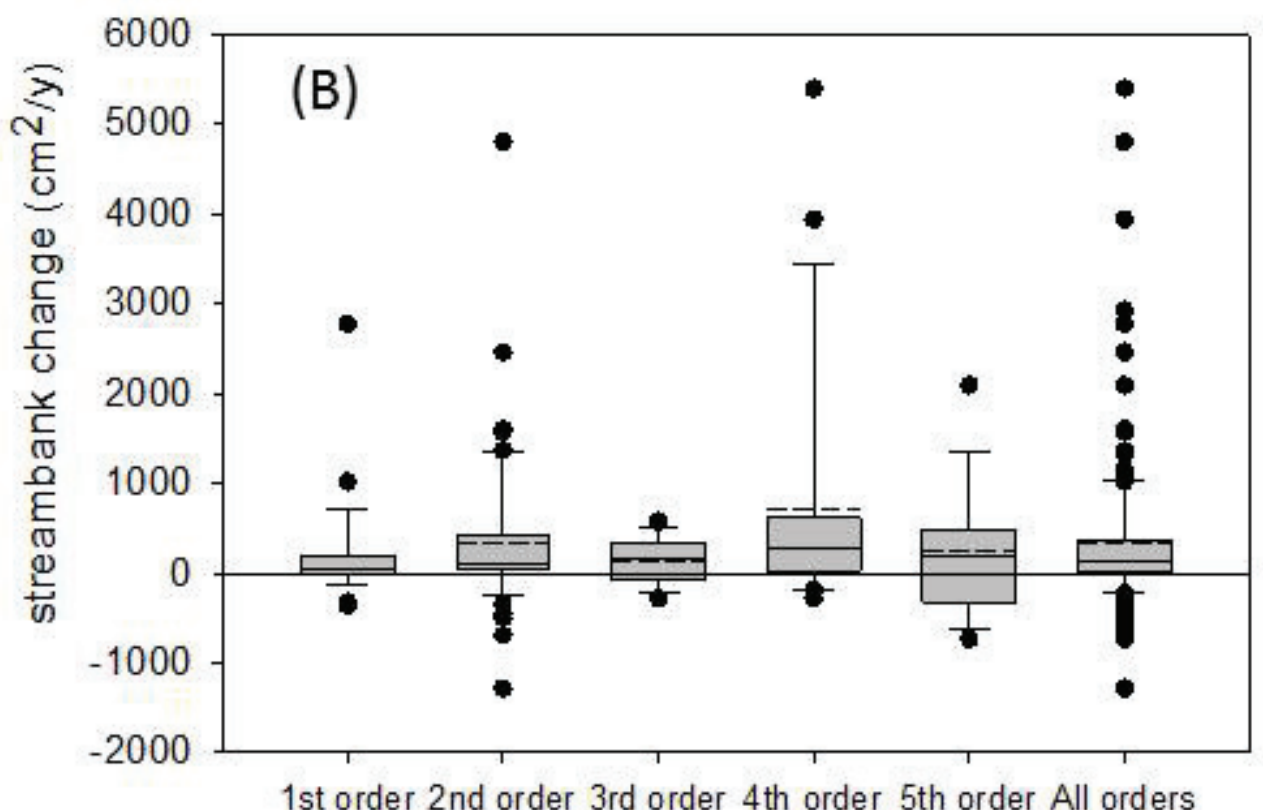

1 st order 2 nd order 3 rd order 4 th order 5 th order All orders
(C)
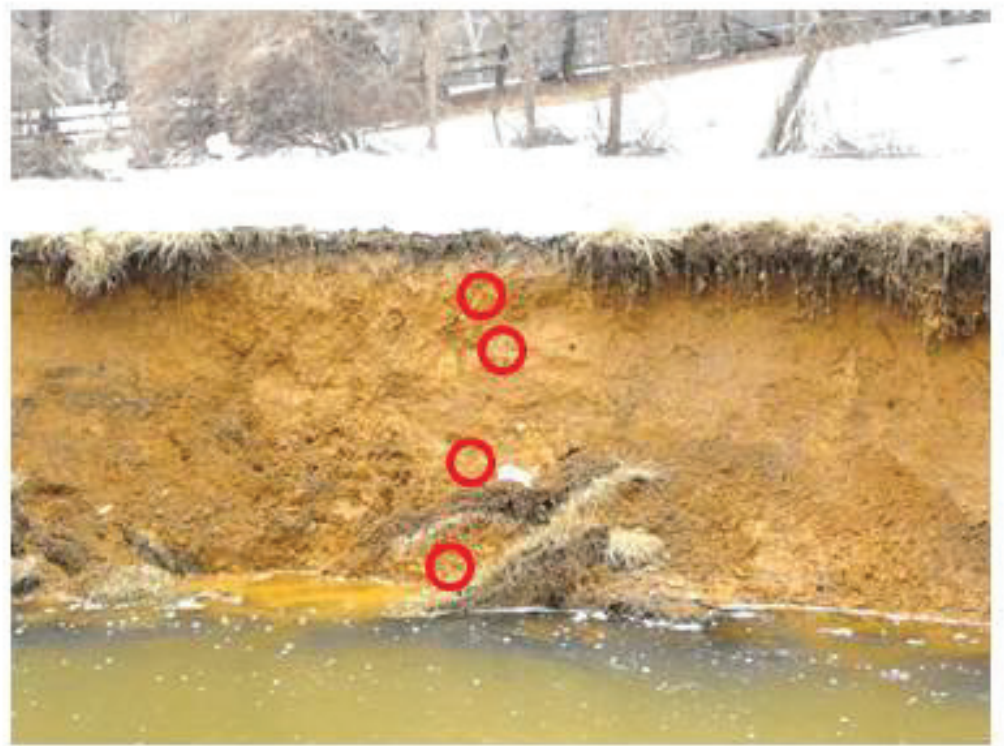

EXPLANATION

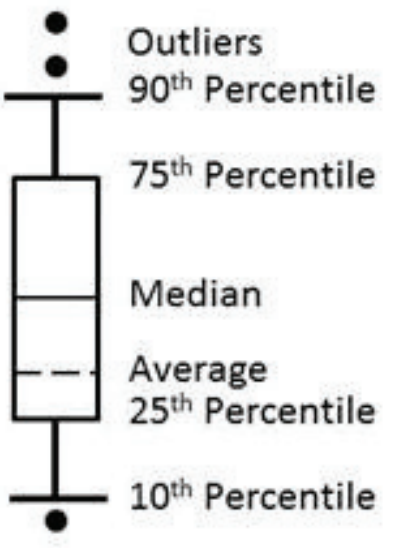




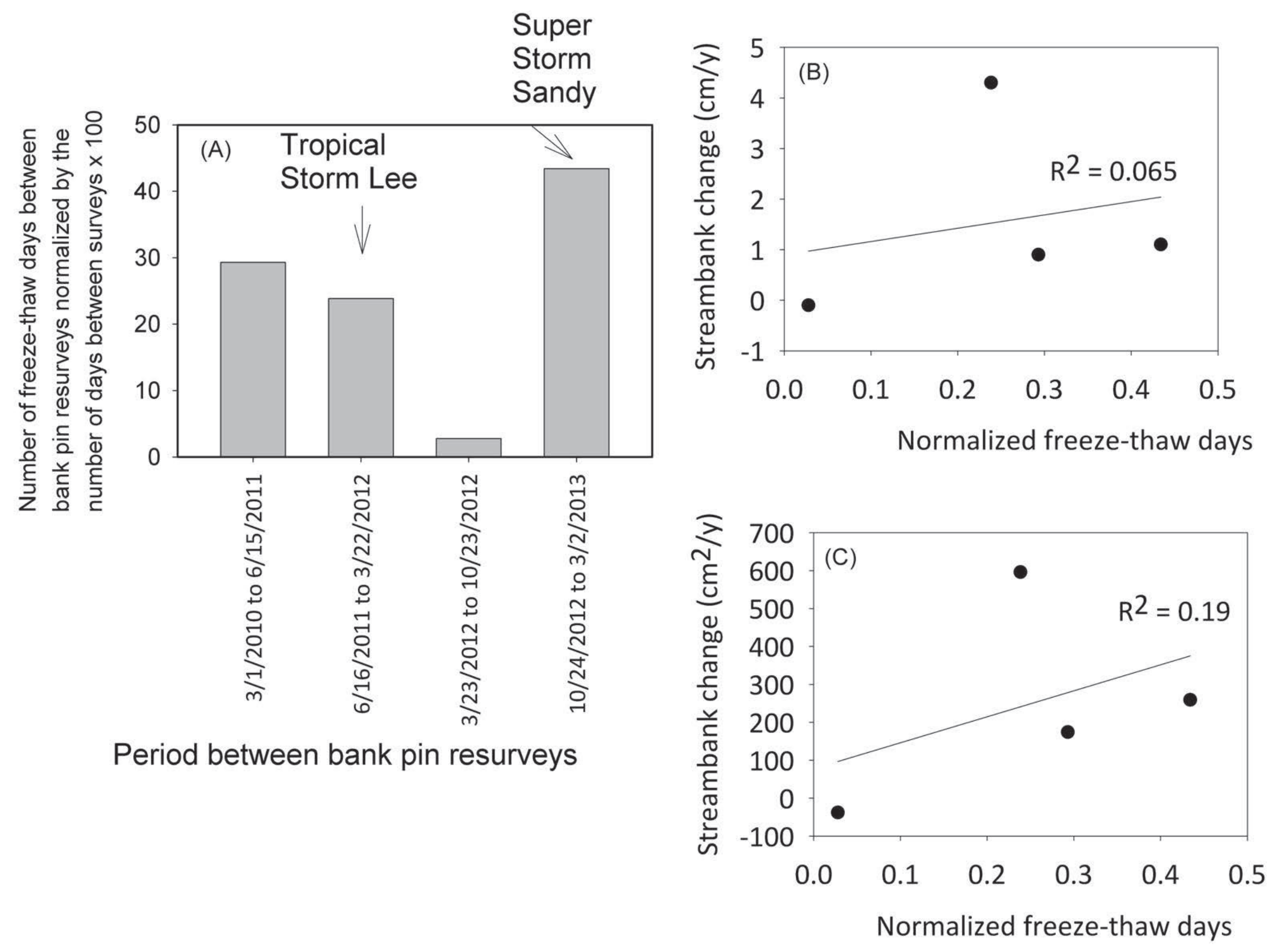



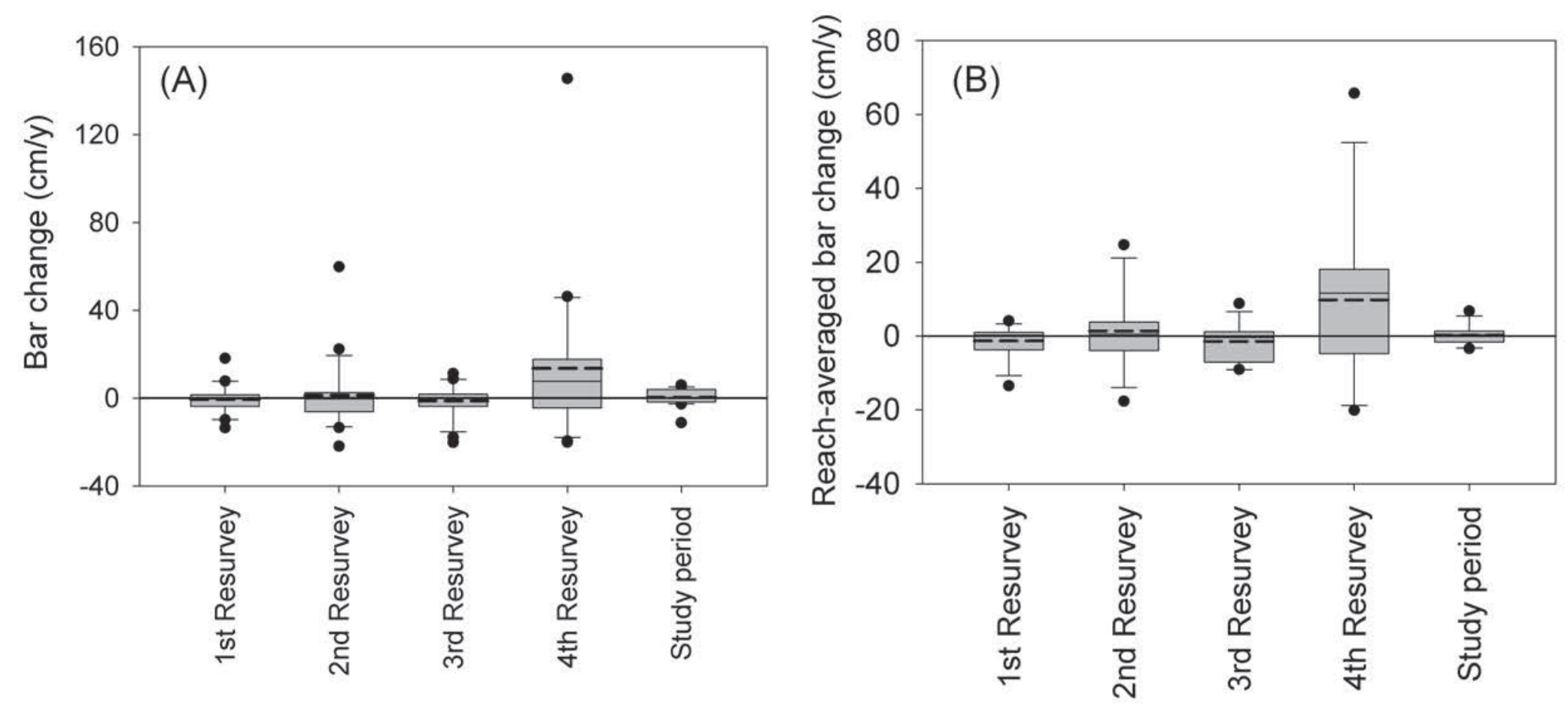

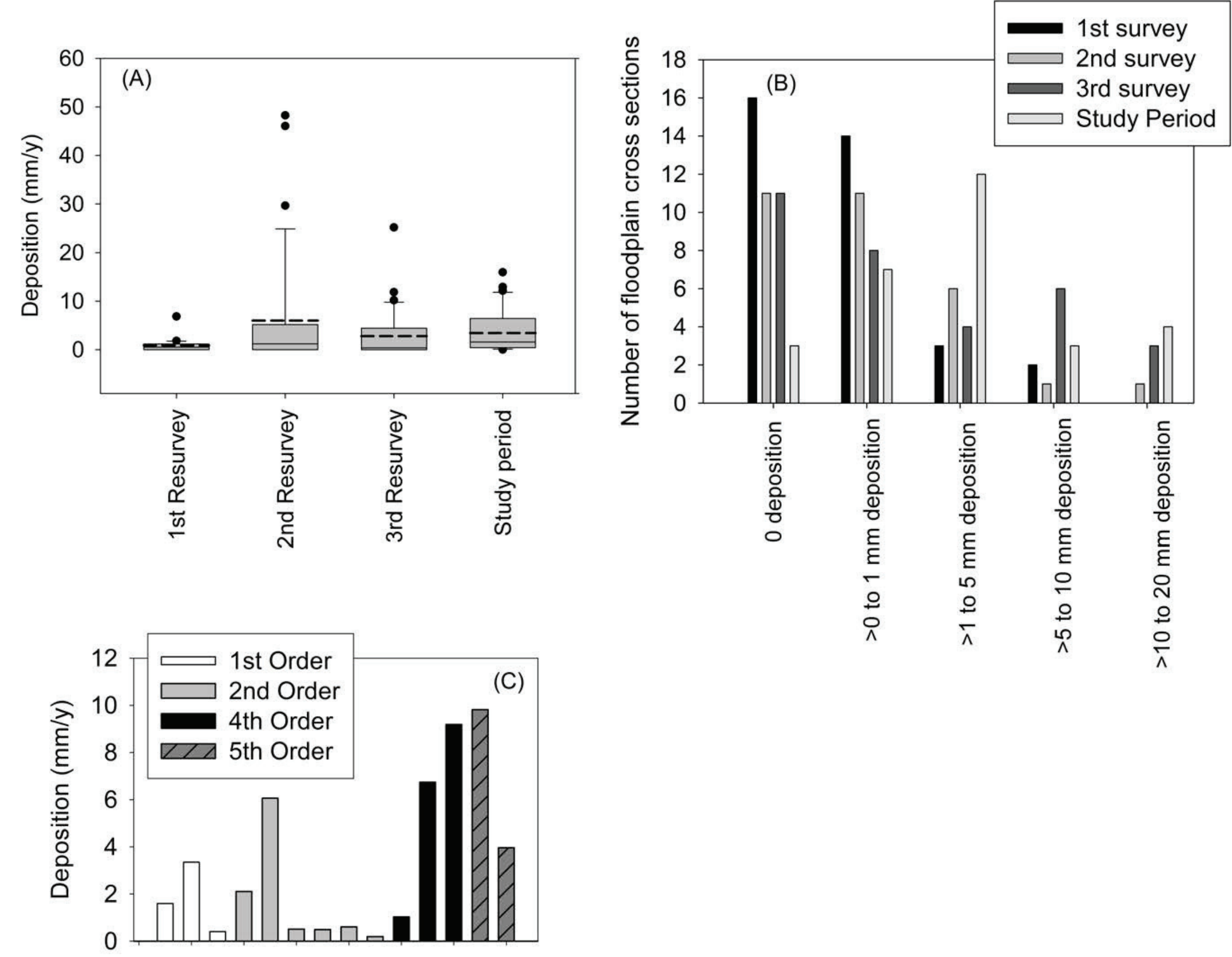

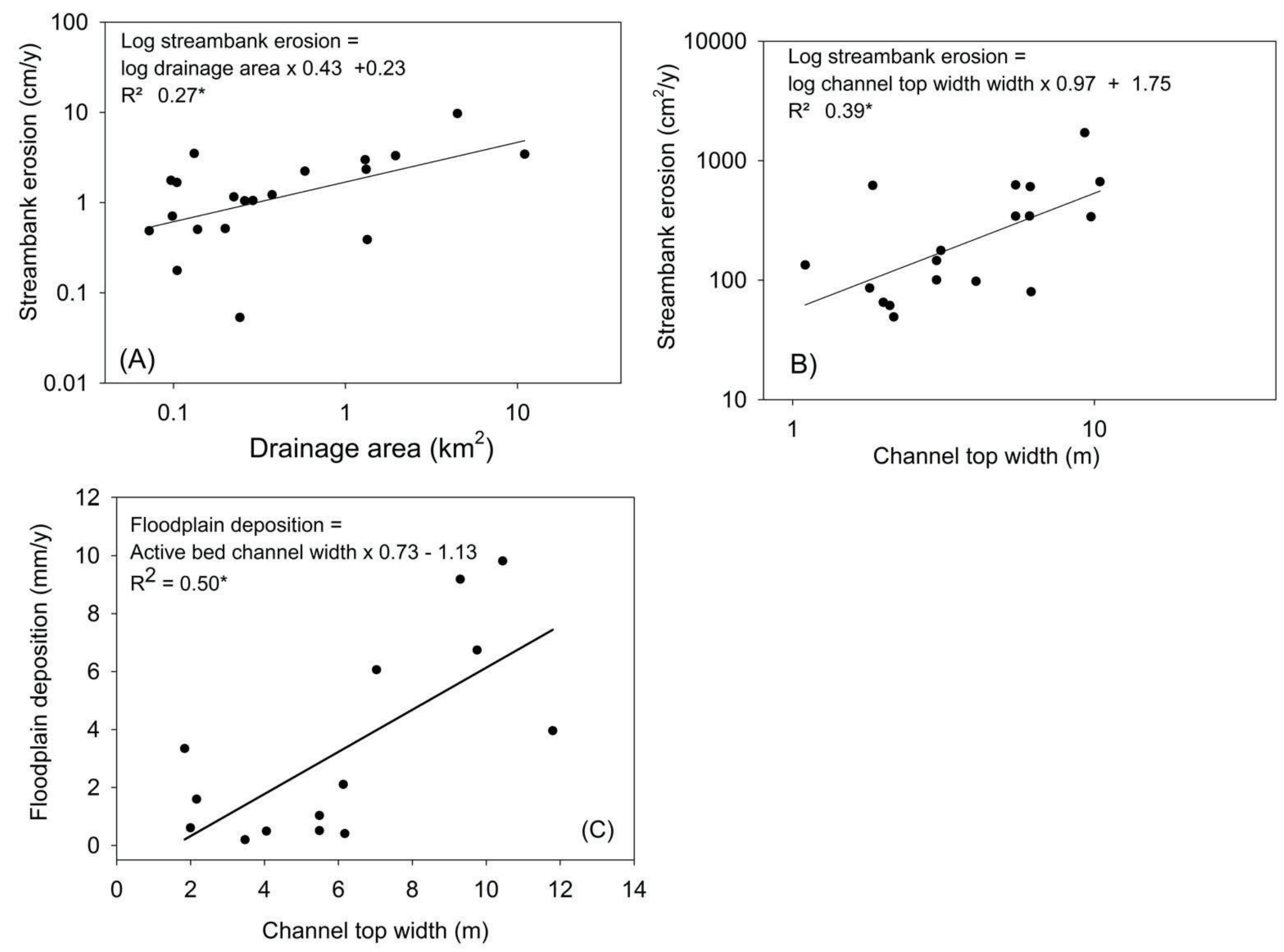


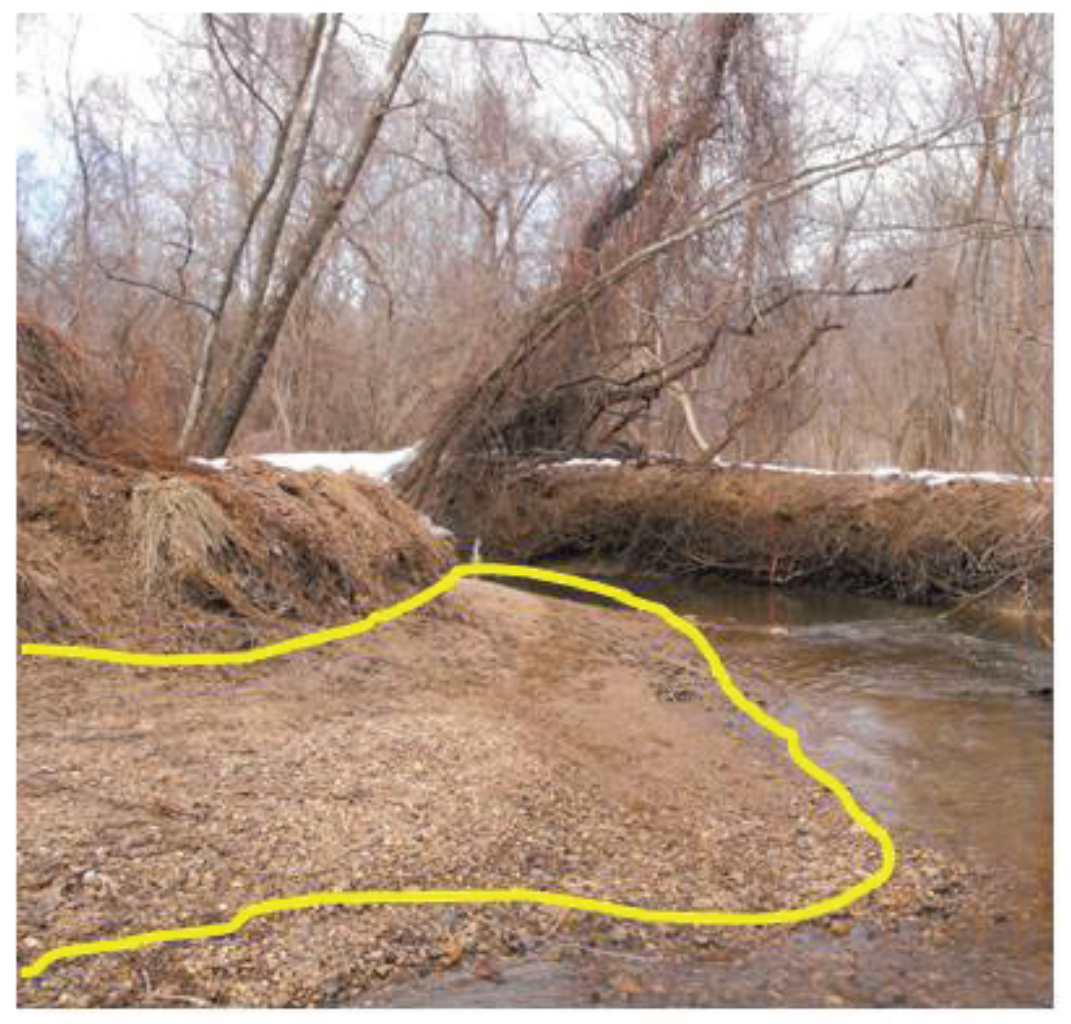




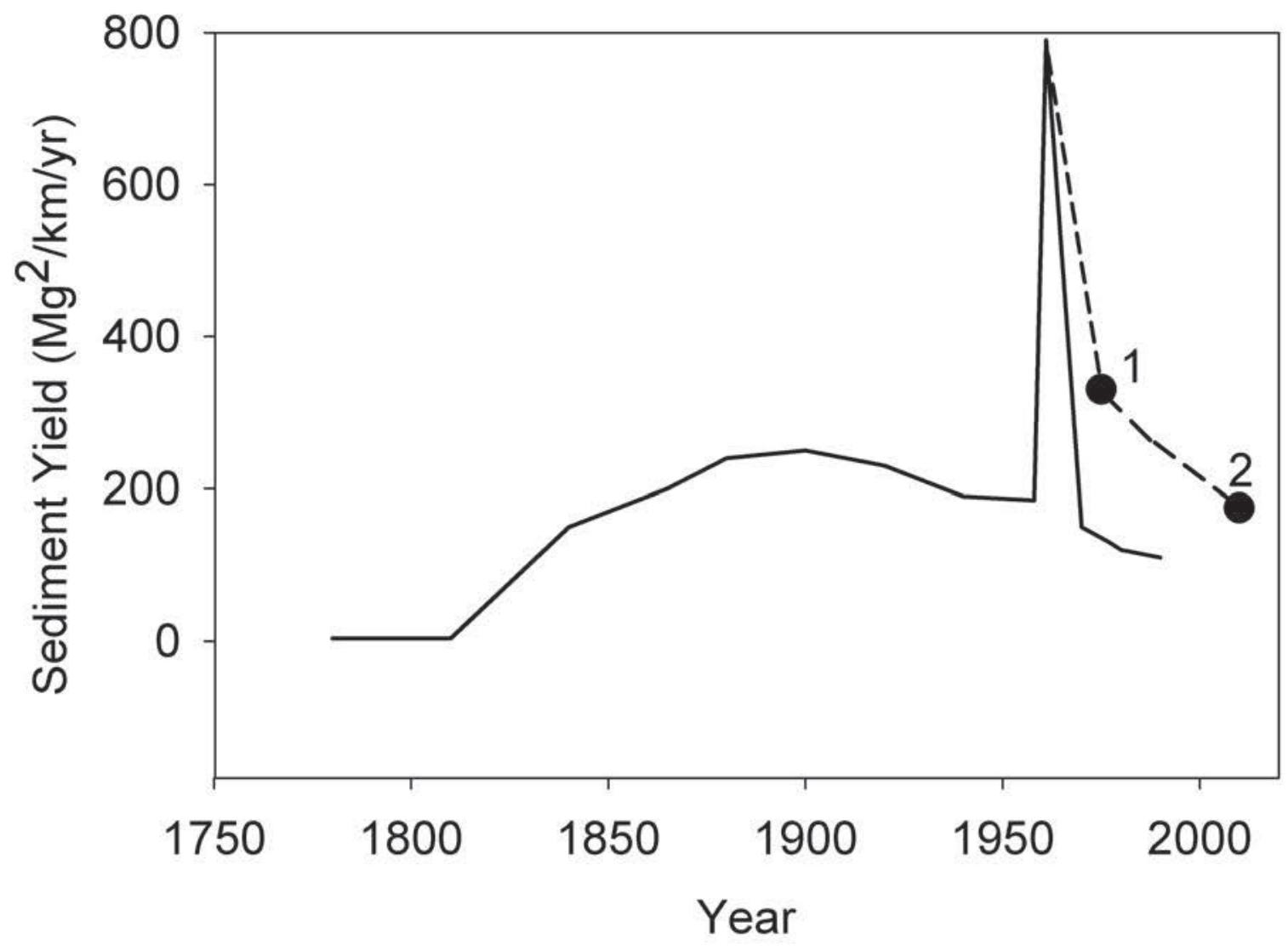

Wolman Curve (Wolman, 1967)

Average of sediment yield data for Washington D.C. area for periods:

1 - 1963-78 - Maryland and Virginia (Gellis et al., 2005);

2 -2005-11 Maryland (Miller et al., 2013) and 2008-12 Virginia (Jastram, 2014) 